\title{
Impact of ocean resolution and mean state on the rate of AMOC weakening
}

\author{
L. C. Jackson ${ }^{1}$ (1) M. J. Roberts ${ }^{1} \cdot$ H. T. Hewitt ${ }^{1}$. D. lovino ${ }^{2} \cdot$ T. Koenigk $^{3} \cdot$ V. L. Meccia ${ }^{4} \cdot$ C. D. Roberts ${ }^{5}$. \\ Y. Ruprich-Robert ${ }^{6} \cdot$ R. A. Wood ${ }^{1}$
}

Received: 9 December 2019 / Accepted: 21 June 2020 / Published online: 7 July 2020

(c) The Author(s) 2020

\begin{abstract}
We examine the weakening of the Atlantic Meridional Overturning Circulation (AMOC) in response to increasing $\mathrm{CO}_{2}$ at different horizontal resolutions in a state-of-the-art climate model and in a small ensemble of models with differing resolutions. There is a strong influence of the ocean mean state on the AMOC weakening: models with a more saline western subpolar gyre have a greater formation of deep water there. This makes the AMOC more susceptible to weakening from an increase in $\mathrm{CO}_{2}$ since weakening ocean heat transports weaken the contrast between ocean and atmospheric temperatures and hence weaken the buoyancy loss. In models with a greater proportion of deep water formation further north (in the Greenland-Iceland-Norwegian basin), deep-water formation can be maintained by shifting further north to where there is a greater ocean-atmosphere temperature contrast. We show that ocean horizontal resolution can have an impact on the mean state, and hence AMOC weakening. In the models examined, those with higher resolutions tend to have a more westerly location of the North Atlantic Current and stronger subpolar gyre. This likely leads to a greater impact of the warm, saline subtropical Atlantic waters on the western subpolar gyre resulting in greater dense water formation there. Although there is some improvement of the higher resolution models over the lower resolution models in terms of the mean state, both still have biases and it is not clear which biases are the most important for influencing the AMOC strength and response to increasing $\mathrm{CO}_{2}$.
\end{abstract}

Keywords Climate $\cdot$ AMOC $\cdot$ Resolution $\cdot$ Weakening

\section{Introduction}

Climate model projections show a weakening of the Atlantic Meridional Overturning Circulation (AMOC) in response to increased greenhouse gases, however there is a wide

L. C. Jackson

laura.jackson@metoffice.gov.uk

1 Met Office Hadley Centre, Exeter, UK

2 Centro Euro-Mediterraneo sui Cambiamenti Climatici, Bologna, Italy

3 Swedish Meteorological and Hydrological Institute, Norrköping and Bolin Centre for Climate Research, Stockholm, Sweden

4 Institute of Atmospheric Science and Climate (ISAC-CNR), Bologna, Italy

5 ECMWF, Reading, UK

6 Barcelona Supercomputing Center, Barcelona, Spain range in the weakening rates. In particular, the Fifth report of the Intergovernmental Panel on Climate Change (IPCC) concluded that a weakening of the AMOC before 2100 was very likely, but with a range of weakening of $12-54 \%$ for a high-range scenario (Collins et al. 2013). This spread in AMOC response in climate models has been shown to be responsible for some of the model spread in projections of surface temperature (Drijfhout et al. 2012), winter storms over Europe (Woollings et al. 2012) and sea level changes (Pardaens et al. 2011). Hence understanding the spread of AMOC projections is of importance to improving climate projections.

Several previous studies have investigated different rates of AMOC weakening. Gregory et al. (2005) explored an ensemble of climate models and showed that the majority of $\mathrm{AMOC}$ weakening when $\mathrm{CO}_{2}$ was increased was from changes in surface heat fluxes, rather than freshwater fluxes. They also showed a relationship between the AMOC strength and weakening: models with a strong AMOC 
generally had a greater absolute AMOC weakening. A stronger AMOC having a greater weakening has also been seen in other multi-model ensembles (Weaver et al. 2012; Winton et al. 2014).

One factor thought to affect the AMOC strength is the horizontal resolution in the ocean. Many studies have found a stronger AMOC in higher resolution models (Roberts et al. 2016, 2019a; Sein et al. 2018; Menary et al. 2018; Docquier et al. 2019; Hirschi et al. 2020), though other studies have found a weaker AMOC in higher resolution models (Yokohata et al. 2007; Delworth et al. 2012; Winton et al. 2014). Increasing resolution from non-eddying to eddy-permitting (or even eddy-resolving) has been shown to improve biases in the North Atlantic (Small et al. 2014; Menary et al. 2018; Roberts et al. 2018, 2019a; Caldwell et al. 2019). Menary et al. (2015) showed that increasing resolution resulted in warmer and more saline waters in the subpolar gyre, and that this change in the mean state affected mechanisms of variability. Sein et al. (2018) showed that a higher resolution model had a better Gulf Stream and North Atlantic current path. Studies have also shown differences in regions where there is water mass transformation (Sein et al. 2018), convection (Menary et al. 2018) and sinking (Katsman et al. 2018) with resolution.

In this study we show that the low resolution (non-eddying) and medium resolution (eddy-permitting) versions of the third Hadley Centre Global Environmental Model, run in the Global Coupled configuration 3.1 (HadGEM3GC3.1), have different climatological mean states, and different responses to the increase of greenhouse gases. We explore the reasons for these differences, also making use of an ensemble of climate models at different resolutions contributing to the HighResMIP experiments (Haarsma et al. 2016). Section 2 describes the models and experiments used. Section 3 then explores the mean state and change under increases in greenhouse gases in HadGEM3-GC3.1. Section 4 expands the analysis to include a multi-model ensemble and Sect. 5 explores how well the mean states compare with observations. Conclusions are presented in Sect. 6.

\section{Models and data}

\subsection{HadGEM3-GC3.1}

We use simulations from the third Hadley Centre Global Environmental Model, run in the Global Coupled configuration 3.1 (HadGEM3-GC3.1) in two different resolutions. HadGEM3-GC3.1 is a global, coupled climate model with atmosphere, ocean, sea ice and land components. The medium resolution version (HadGEM3-GC3.1$\mathrm{MM}$, referred to here as MR) has an atmospheric resolution of approximately $60 \mathrm{~km}$ and an ocean resolution of $0.25^{\circ}$. The development of the medium resolution version is described in Williams et al. (2018). The low resolution version (HadGEM3-GC3.1-LL, referred to here as LR) has an atmospheric resolution of approximately $135 \mathrm{~km}$ and an ocean resolution of $1^{\circ}$ (with refinement to $0.33^{\circ}$ within $15^{\circ}$ of the equator). The LR version is described in Kuhlbrodt et al. (2018). Other differences are the inclusion of a parameterization for eddy-induced transports in LR that is not included in MR, and some parameter differences (Kuhlbrodt et al. 2018). Both MR and LR use the same vertical resolutions.

We use 150 years of the preindustrial control simulations (CON), described in Menary et al. (2018) and also use idealised experiments where $\mathrm{CO}_{2}$ is increased by $1 \%$ per year for 150 years (1PC). There are three ensemble members for LR and four for MR in the 1PC experiments, starting from different initial conditions in the control. In Figs. 1 and 2, results are shown from all ensemble members to assess significance of the differences. However in the remainder of the study we use results from the first ensemble member only. We also make use of historical simulations for comparison with observations.

For some analysis we use decadal means. The AMOC has variability on decadal timescales, and hence this may affect decadal values, however signals from increasing $\mathrm{CO}_{2}$ are large compared with the variability (see Fig. 2).

\subsection{PRIMAVERA ensemble}

The PRIMAVERA-HighResMIP multi-model ensemble of simulations use the CMIP6 HighResMIP experimental design (Haarsma et al. 2016). This comprises a multi-decadal spinup using fixed 1950s forcings, followed by a historical and future scenario (RCP585) from 1950-2050 and a parallel control simulation with fixed 1950s forcings. The set up and forcings are described in more detail in Haarsma et al. (2016) and Roberts et al. (2019a).

The models configured for HighResMIP and used here are as follows: ECMWF-IFS (Roberts et al. 2018); CNRMCM6-1 (Voldoire et al. 2019); CMCC-CM2-(V)HR4 (Cherchi et al. 2019); HadGEM3-GC3.1 (Roberts et al. 2019a); EC-Earth3P (Haarsma et al. 2020). The model parameter settings are discussed in Docquier et al. (2019) and Roberts et al. (2019b). Note that all these coupled models use the NEMO ocean model, though with a range of configurations. The different models and effective resolutions are shown in Table 1. Of these models we note that ECMWF-IFS only provided the experiment with fixed 1950s forcings so is not included in some figures. 

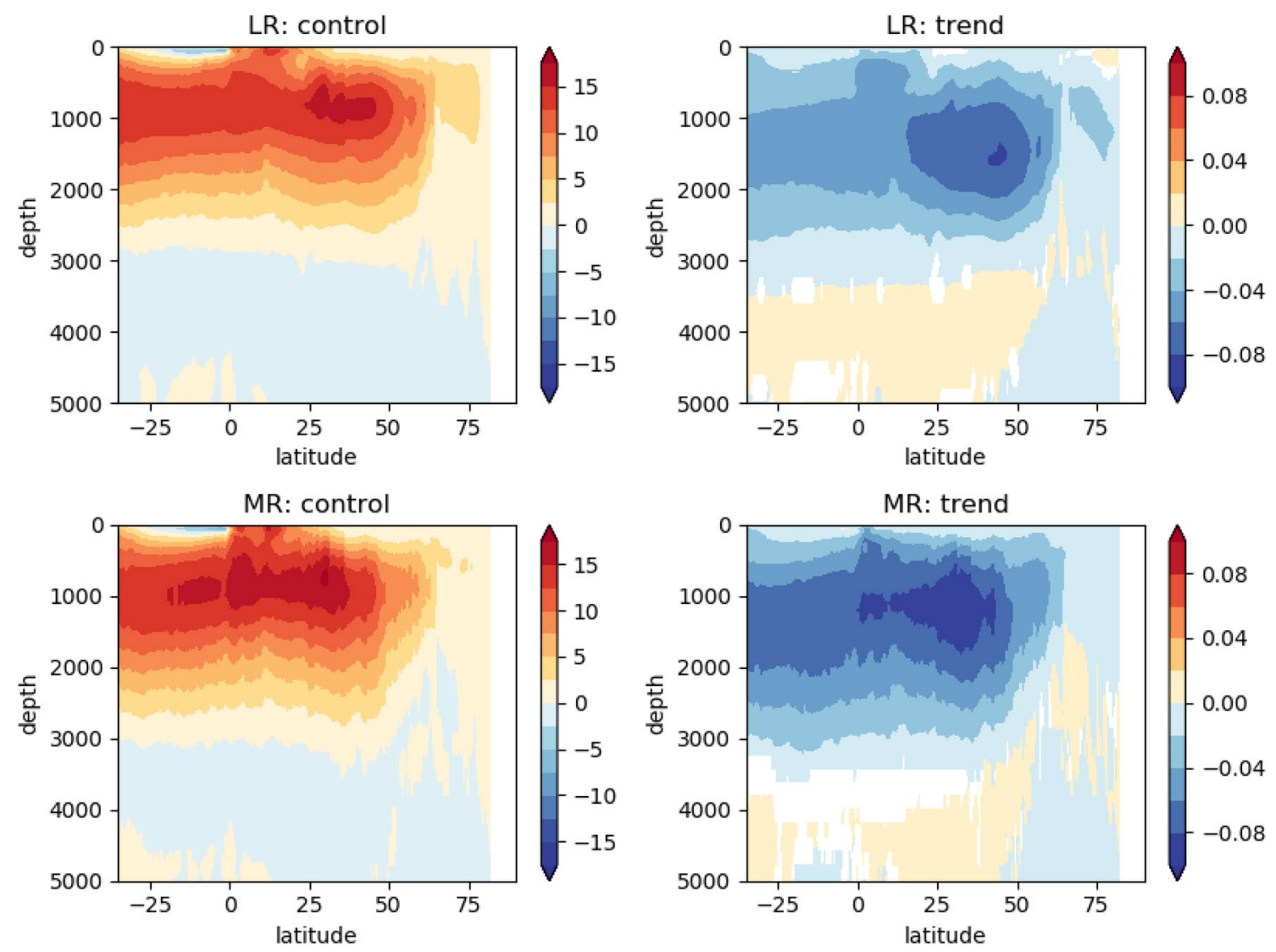

Fig. 1 The time-mean, ensemble mean AMOC streamfunctions in CON (left, Sv) and trend of AMOC in 1PC (right, Sv/yr). Unshaded regions are where the trend is not significant (where the trend is

\subsection{Observational data}

We compare climate model data to observational data from several sources. Firstly we use the gridded temperature and salinity data sets of EN4 (Good et al. 2013) and CORA (Cabanes et al. 2013). The former has data from 1900 to the present and the latter from 1990. We calculate climatologies for the preindustrial period using years 1900-1950 from EN4 only. Although this period is not preindustrial, changes in the climate from preindustrial are found to be smaller than differences between the models and between models and observations. We also use a present day period (2000-2014) for both EN4 and CORA. This period has many more observations and hence the observational data set are much better constrained, however an assessment of present day conditions is also assessing the changes in the model from the preindustrial period in response to increasing greenhouse gases and changes in aerosols. However we find that the changes in both the observations and models from the preindustrial period to present day are relatively small in comparison to the differences between the models and between models and observations.

smaller than twice the ensemble standard deviation). Top panels show the AMOC for LR and bottom panels for MR

We also use continuous observations of the AMOC from two locations. The RAPID array (McCarthy et al. 2015) has measured the AMOC in depth space at $26.5^{\circ} \mathrm{N}$ since 2004 (with 14 years of data available), and the OSNAP array (Lozier et al. 2017) has measured the AMOC in density space along a transect at around $50^{\circ}-60^{\circ} \mathrm{N}$ since 2014 (with 21 months of data available). There may be have been changes in the AMOC since the preindustrial period, however the AMOC is also understood to have large variability on different timescales (Buckley and Marshall 2016). Hence in comparison with model timeseries we construct a probability density function of time means of 14 years or 21 months long respectively.

\section{HadGEM3-GC3.1 results}

\subsection{AMOC mean state and response}

In both resolutions of HadGEM3-GC3.1 there is a clear AMOC cell in the preindustrial experiments (Fig. 1, left). This cell is stronger in MR than LR, other than in the 

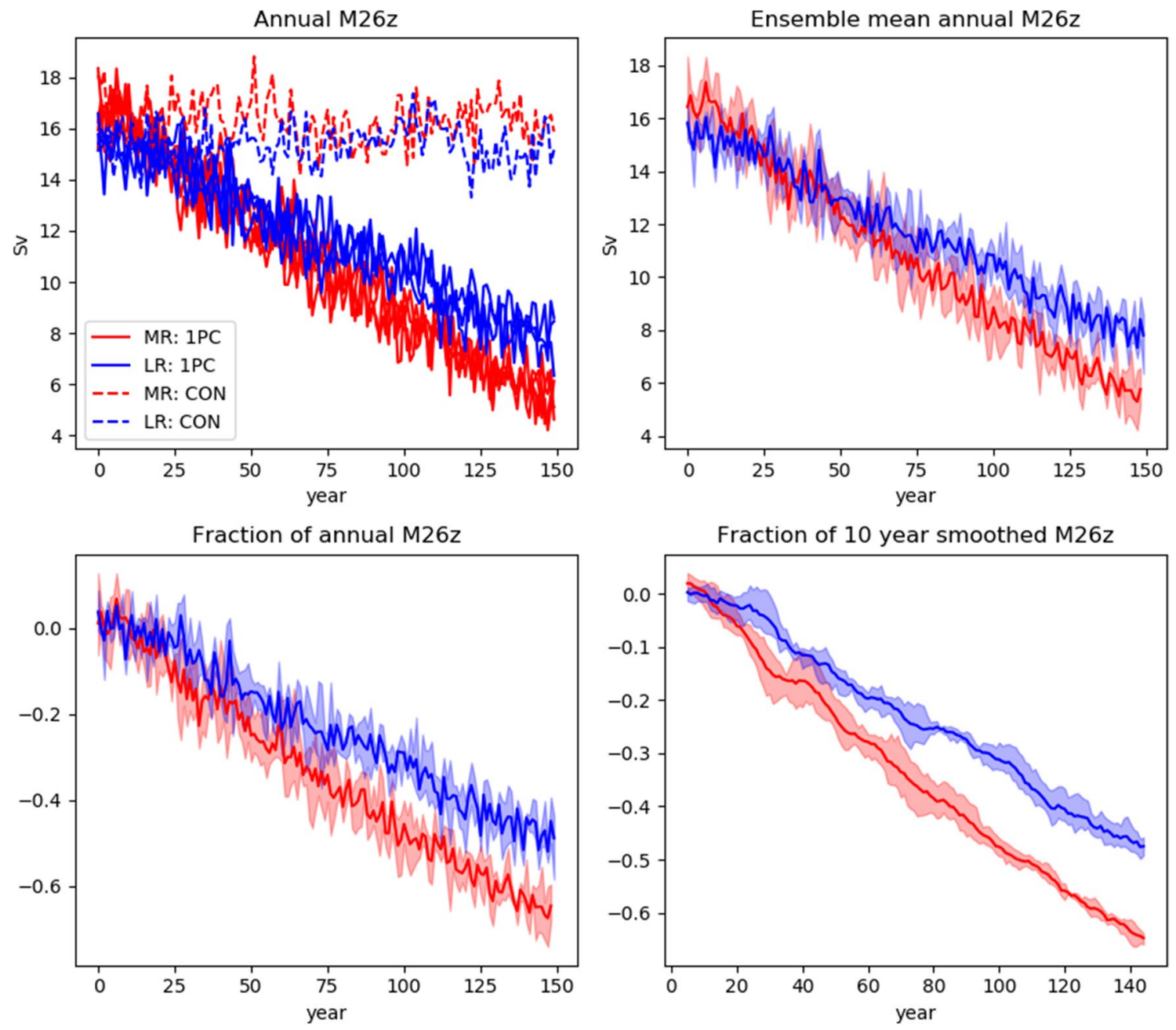

Fig. 2 AMOC (M26z) timeseries for MR (red) and LR (blue). Top left: timeseries for CON (dashed) and individual ensemble members for 1PC (solid). Top right: ensemble mean. Bottom left: As top right

but for fractional anomaly. Bottom right: as bottom left but having first applied a 10 year running mean. Shading shows the ensemble range

Table 1 PRIMAVERA models

\begin{tabular}{llcll}
\hline Model & Atmospheric model & $\begin{array}{l}\text { Atmosphere } \\
\text { resolution }(\mathrm{km})\end{array}$ & Ocean/ice model & Ocean resolution \\
\hline CMCC-CM2-HR4 & CAM4 & 100 & NEMO3.6/CIC4.0 & $0.25^{\circ}$ \\
CMCC-CM2-VHR4 & CAM4 & 25 & NEMO3.6/CIC4.0 & $0.25^{\circ}$ \\
CNRM-CM6-1 & ARPEGE6.3 & 250 & NEMO3.6/GELATO & $1^{\circ}$ \\
CNRM-CM6-1-HR & ARPEGE6.3 & 50 & NEMO3.6/GELATO & $0.25^{\circ}$ \\
EC-Earth3P & IFS cycle 36r4 & 100 & NEMO3.6/LIM3 & $1^{\circ}$ \\
EC-Earth3P-HR & IFS cycle 36r4 & 50 & NEMO3.6/LIM3 & $0.25^{\circ}$ \\
ECMWF-IFS-LR & IFS cycle 43r1 & 50 & NEMO3.4/LIM2 & $1^{\circ}$ \\
ECMWF-IFS-HR & IFS cycle 43r1 & 25 & NEMO3.4/LIM2 & $0.25^{\circ}$ \\
HadGEM3-GC31-LL & UM & 250 & NEMO3.6/CICE5.1 & $1^{\circ}$ \\
HadGEM3-GC31-MM & UM & 100 & NEMO3.6/CICE5.1 & $0.25^{\circ}$ \\
HadGEM3-GC31-HM & UM & 50 & NEMO3.6/CICE5.1 & $0.25^{\circ}$ \\
\hline
\end{tabular}



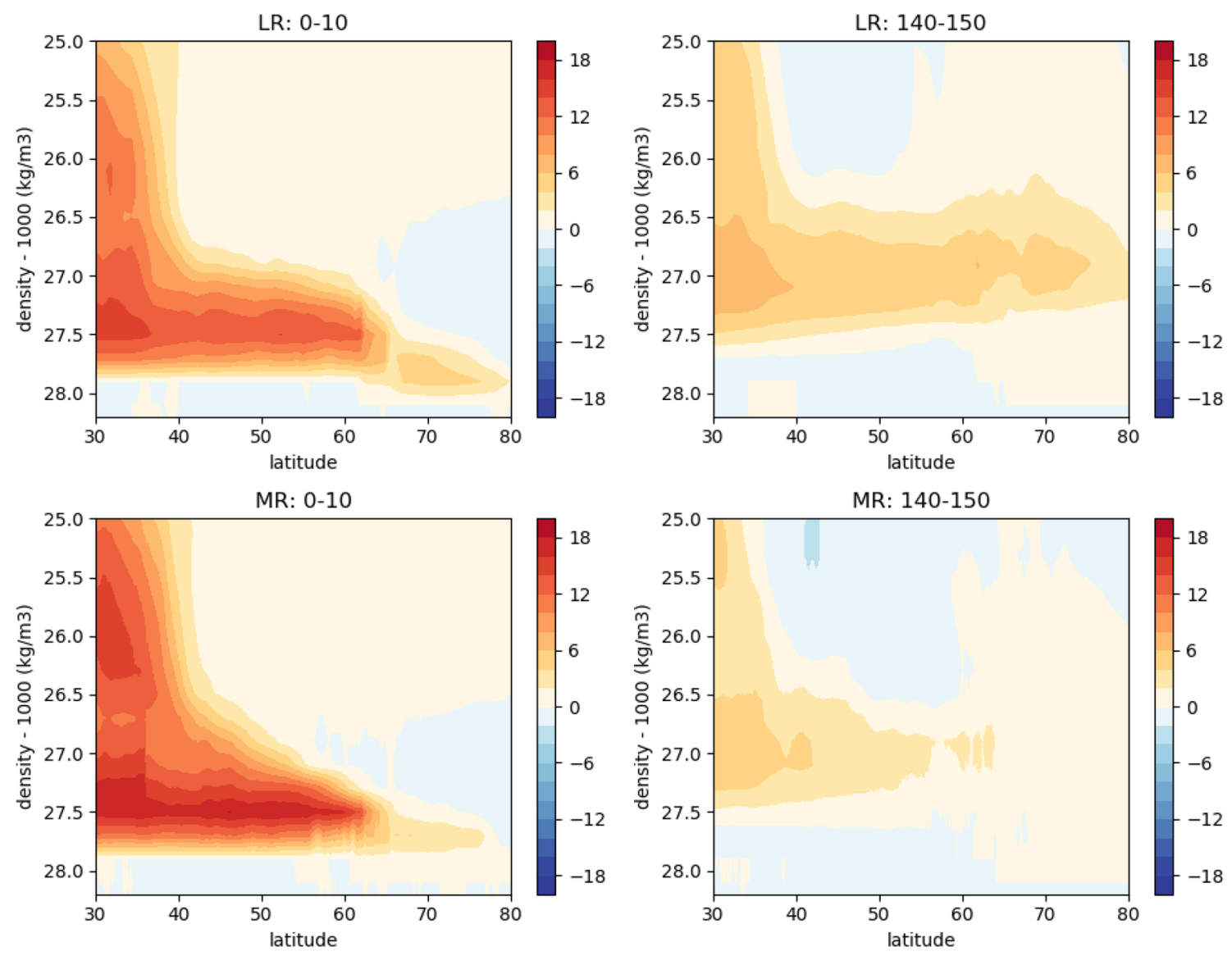

Fig. 3 AMOC streamfunctions (Sv) in density space as decadal means for LR (top) and MR (bottom). Left: time mean for first decade of 1PC (0-10). Right: time mean for last decade of 1PC (140-150)

subpolar North Atlantic and the GIN (Greenland-IcelandNorwegian) seas where the cell is stronger and deeper in LR. In the subpolar gyre, although the AMOC is weaker in MR than LR in depth coordinates, it is stronger in density coordinates (Fig. 3, left). Similar results are found in Hirschi et al. (2020). However the GIN seas overturning is weaker in MR in both coordinates.

In the experiments where $\mathrm{CO}_{2}$ concentrations are increased at $1 \%$ per year (1PC) there is a strong weakening of the AMOC in both models, which is nearly linear (Fig. 2). The metric used here is the maximum AMOC in depth space at $26.5^{\circ} \mathrm{N}(\mathrm{M} 26 \mathrm{z})$. The AMOC in MR starts stronger but weakens more quickly and to a lower value than LR. The trends of the ensemble means are $0.055 \mathrm{~Sv} /$ year in LR and $0.078 \mathrm{~Sv} / y e a r$ in MR. By the time of $\mathrm{CO}_{2}$ doubling (mean of years 135-145) LR has weakened by $7.2 \pm 0.7 \mathrm{~Sv}$, or $47 \% \pm 4 \%$; and MR has weakened by $10.4 \pm 0.5 \mathrm{~Sv}$ or $64 \%$ $\pm 3 \%$ (uncertainties are twice the standard deviation across the ensembles). The two ensembles are clearly statistically different with a greater absolute and fractional weakening for the higher resolution model.
The weakening is significant across the whole AMOC cell in both MR and LR (Fig. 1, right) with a greater weakening in MR throughout the cell, with the exception of north of $50^{\circ} \mathrm{N}$ (ie the subpolar North Atlantic and GIN seas). We note that in both resolutions the AMOC shallows as it weakens, resulting in a greater trend in the lower part of the cell. In density space (Fig. 3) both models show a clear weakening of the circulation south of $67^{\circ} \mathrm{N}$, and a shift to lighter densities. The AMOC at $45^{\circ} \mathrm{N}$ in density space (M45) weakens more in MR than LR, both in absolute terms and in percentage terms (see Table 2). The AMOC at $67^{\circ} \mathrm{N}$ in density space (M67) is initially stronger in LR than MR. This overturning weakens little in LR, but shifts to a much lighter density class.

If we regard the overturning north of $45^{\circ}$ or $67^{\circ} \mathrm{N}$ as the transformation into deeper density classes north of $45^{\circ}$ or $67^{\circ} \mathrm{N}$, then the difference is the transformation in the subpolar gyre between $45^{\circ}$ and $67^{\circ} \mathrm{N}$. Figure 4 shows the profiles at $45^{\circ}$ and $67^{\circ} \mathrm{N}$ as well as the difference between them. This highlights that there is very little difference in overturning between $45^{\circ}$ and $67^{\circ} \mathrm{N}$ in both models at the end of the $1 \mathrm{PC}$ experiment and that the majority of the overturning 

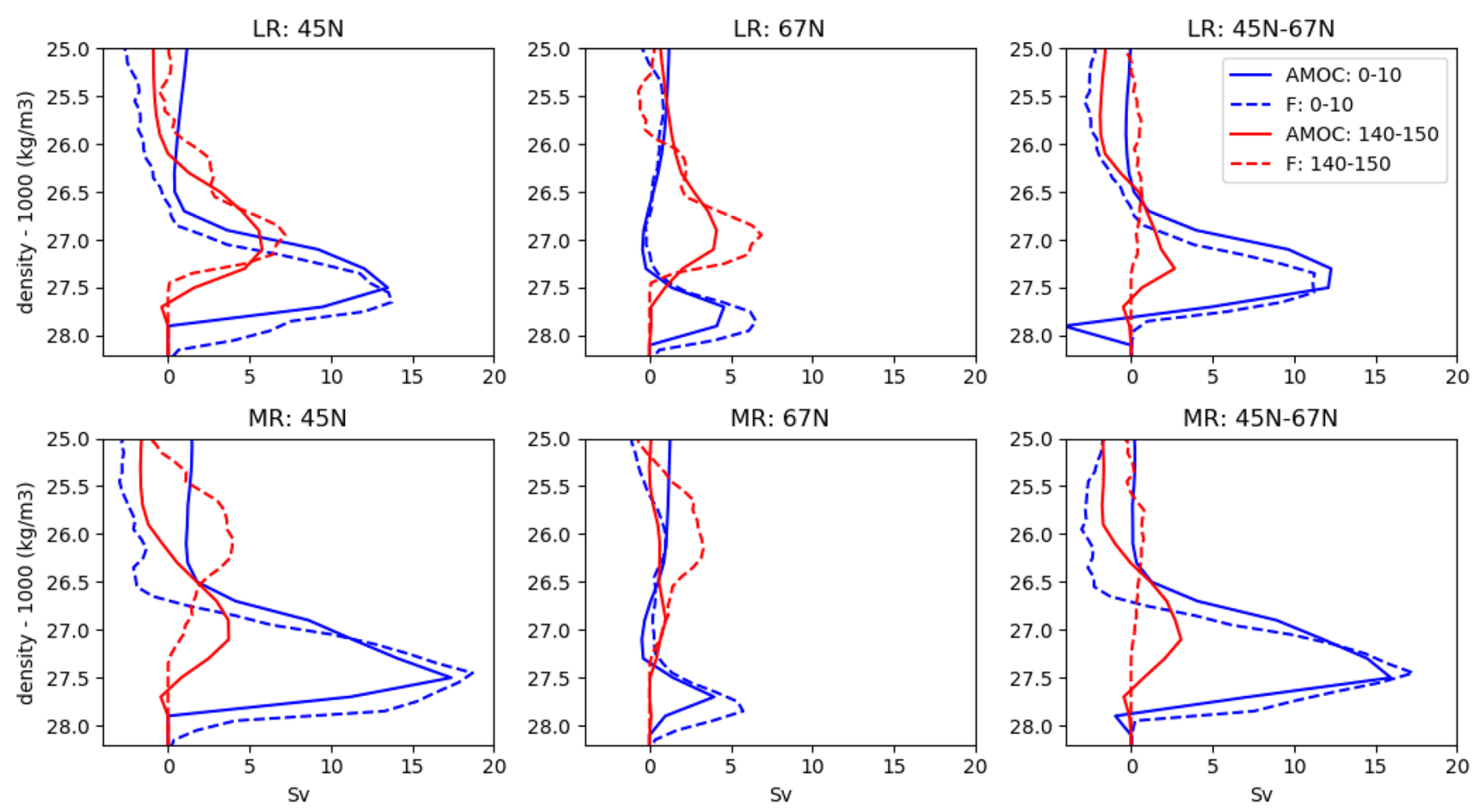

Fig. 4 AMOC (density space) profiles at $45^{\circ}, 67^{\circ} \mathrm{N}$ and the difference between them. Dashed lines are AMOC profiles implied from surface fluxes ( $F$, see "Appendix"). Blue lines are from the first 10 years of the experiment $(0-10)$ and red lines are from the last 10 years (140-150). Values for lighter densities are not shown

Table 3 As Table 2, but for the overturning in density space implied by density transformation

\begin{tabular}{lllll}
\hline Model & Year & $45^{\circ} \mathrm{N}$ & $67^{\circ} \mathrm{N}$ & $45^{\circ}-67^{\circ} \mathrm{N}$ \\
\hline LR & $0-10$ & 13.7 & 6.5 & 11.3 \\
& $140-150$ & 7.2 & 6.9 & 0.7 \\
& $\Delta$ & $6.5(47 \%)$ & $-0.3(-5 \%)$ & $10.6(94 \%)$ \\
MR & $0-10$ & 18.7 & 5.7 & 17.3 \\
& $140-150$ & 4.0 & 3.3 & 0.8 \\
& $\Delta$ & $14.7(79 \%)$ & $2.4(43 \%)$ & $16.5(95 \%)$ \\
\hline
\end{tabular}

Columns 3 and 4 show values for latitudes $45^{\circ} \mathrm{N}$ and $67^{\circ} \mathrm{N}$, calculated as the maximum of the streamfunction at that latitude in density space. Column 5 shows the maximum of the difference in streamfunction between $45^{\circ} \mathrm{N}$ and $67^{\circ} \mathrm{N}$. Rows show values at different decades. The difference $\Delta$ is between the two time periods and the percentage change calculated with respect to the initial period

comes from the GIN seas (north of $67^{\circ} \mathrm{N}$ ). This is emphasised further if we calculate the overturning implied by surface buoyancy fluxes ( $F$, see "Appendix"). The profiles of implied overturning show good agreement with the AMOC profiles, with differences in the density classes of MR at the end of the 1PC experiment likely to be because the density transformation and overturning are not sufficiently in equilibrium. There are also differences because the implied overturning is only from surface fluxes and does not include density changes from mixing and cabbelling. The implied overturning shows that there is no density transformation to a deeper density class between $45^{\circ}$ and $67^{\circ} \mathrm{N}$ at the end of the 1PC experiments in either model so the overturning seen there is either from diapycnal mixing or because the state is not in equilibrium.

Since the overturning between $45^{\circ}$ and $67^{\circ} \mathrm{N}$ and that north of $67^{\circ} \mathrm{N}$ respond differently to the increase in $\mathrm{CO}_{2}$ we can consider how this impacts the total AMOC weakening experienced in each model. North of $67^{\circ} \mathrm{N}$ there is some weakening of the overturning, though this is smaller than the weakening between $45^{\circ}$ and $67^{\circ} \mathrm{N}$, where there is a large weakening of $\sim 80 \%$ in both models (Table 2). The overturning implied by the density transformation (Table 3) shows this even more clearly, with 
the majority of the weakening occuring between $45^{\circ}$ and $67^{\circ} \mathrm{N}$, and the density transformation to denser classes there showing a nearly complete cessation. If we were to assume that the overturning north of $67^{\circ} \mathrm{N}\left(M_{G I N}\right)$ did not change $\left(\Delta M_{G I N}=0\right)$ and the overturning between $45^{\circ}$ and $67^{\circ} \mathrm{N}\left(M_{S P G}\right)$ completely shut down $\left(\Delta M_{S P G}=M_{S P G}\right)$ then the fractional change in the AMOC would be $\left(\Delta M_{G I N}+\Delta M_{S P G}\right) /\left(M_{G I N}+M_{S P G}\right)=\left(M_{G I N} / M_{S P G}+1\right)^{-1}$ (where $M_{G I N}$ and $M_{S P G}$ are the values in the control). Hence the model with the greatest proportion of $M_{S P G}$ relative to $M_{G I N}$ in the control has the greatest fractional weakening. Since MR has a greater proportion of overturning and water mass transformation occuring south of $67^{\circ} \mathrm{N}$ we would therefore expect it to have a greater fractional weakening. Previous studies have found that models with stronger AMOC have a greater AMOC weakening when $\mathrm{CO}_{2}$ is increased (Gregory et al. 2005; Weaver et al. 2012; Winton et al. 2014). When considering fractional change, the results are less clear: only Winton et al. (2014) shows a relationship, with a clear increase in fractional weakening when the AMOC is stronger.

\subsection{Location of density transformation}

The previous section discussed how the location of density transformation in the mean state could influence the weakening when $\mathrm{CO}_{2}$ increases. To examine this in more detail we show the surface buoyancy fluxes for the two models and for the first and last decade of the 1PC experiment (Fig. 5). The majority of the density transformation to denser water classes in the first decade (0-10) occurs in the east SPG with transformation also in the west SPG and GIN seas (fourth row of Fig. 5). This transformation is mainly due to heat loss, though there is a little freshening from greater precipitation than evaporation, and from sea ice melt in the GIN seas (not shown). Isolating transformations from different density classes shows transformation of the lighter waters in the east SPG (row 1), then denser waters in the north-east SPG (row 2) and densest waters in the west SPG and GIN seas (row 3 of Fig. 5). Hence water travels anticlockwise around the SPG, and northwards into the GIN seas, becoming denser from surface fluxes. The MR model has greater transformation of light to mid-density waters in the east SPG and in the Gulf Stream extension than LR, likely because surface waters are warmer (not shown). For the transformation of the mid to dense water, MR has more in the west SPG (south of $67^{\circ} \mathrm{N}$ ), but less in the GIN seas (north of $67^{\circ} \mathrm{N}$ ) than LR. This is consistent with the streamfunctions in density space (Fig. 4).

At the end of the 1PC experiment, both models show very little transformation to denser water classes south of $67^{\circ} \mathrm{N}$. In fact much of the SPG is losing density, mainly through gaining heat, since the atmosphere has warmed more than the ocean. The transformation to denser water in the GIN seas has shifted further northwards since, because the atmosphere has warmed more than the ocean, the water has to travel to a higher latitude where the atmospheric temperature is relatively cooler to lose heat.

Density transformation occurs at the surface, but changes in stratification impact convection and hence subsurface properties, leading to changes in vertical sinking and hence the AMOC (Spall 2004; Katsman et al. 2018). Mixed layer depths (a proxy for deep convection) are shown in Fig. 6. In the first decade these show that the west SPG is the most important deep convection site in MR and that the GIN seas is the most important for LR. This is consistent with locations of the densest density transformations. At the end of the 1PC experiment, both models show no deep convection south of $67^{\circ} \mathrm{N}$.

\subsection{Role of the mean state}

To understand why the two models have different preferential locations for density transformation we examine the water mass properties (Fig. 7). The upper ocean in the west SPG is warmer and saltier in MR than LR. Salinity dominates the effect on density resulting in the upper ocean being denser and less stratified (see later discussion of Fig. 15). This is consistent with the deeper west SPG MLD in MR. Since the upper ocean is warmer in MR than LR, despite having more surface heat loss (ie a density gain, see Fig. 5), we can conclude that MR in the west SPG has a greater influence of warm, salty waters originating from the North Atlantic than does LR. The opposite is true in the GIN seas, where LR has a warmer and saltier upper ocean, implying a greater influence of water from the North Atlantic.

If we examine the circulation integrated over the upper $500 \mathrm{~m}$ (Fig. 8) we can see the MR has a stonger subpolar circulation. The full-depth subpolar gyre strength is also stronger (not shown). Warm and salty subtropical waters are transported northwards in the North Atlantic current and then recirculated westwards into the west SPG and northwards into the east GIN seas. Figure $8 \mathrm{c}$ shows that the eastwards transport in the upper waters towards the west SPG is stronger in MR, consistent with the stronger subpolar gyre strength. This leads to a greater transport of warm and salty North Atlantic water into the west SPG. The transports of upper water $(<500 \mathrm{~m})$ into the GIN seas between Iceland and Scotland is stronger in LR (7.8 Sv and 5.8 Sv in LR and MR respectively), consistent with MR having a stronger overturning transport into the GIN seas (Fig. 3). This greater transport of North Atlantic waters into the GIN seas in LR results in the greater temperature and salinity in the east GIN seas.

Figure 8 shows that the path of the North Atlantic current is in a more westerly location in MR than LR. This can also 


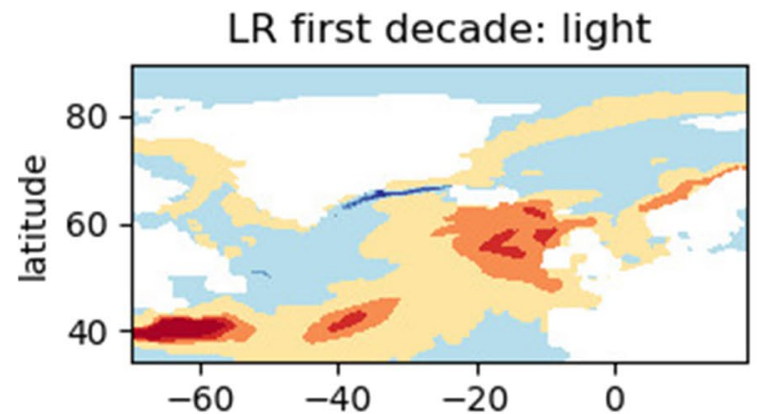

LR first decade: medium

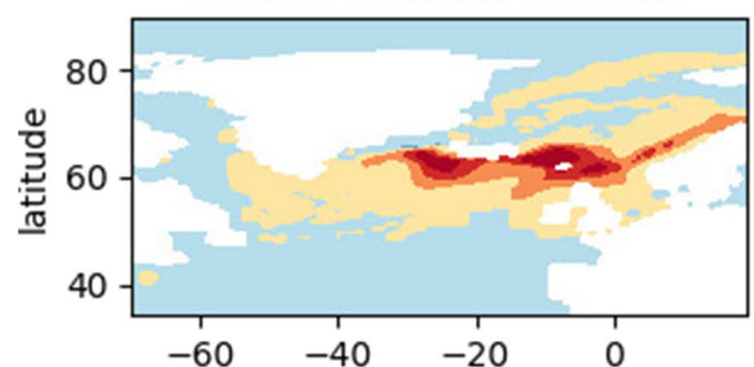

LR first decade: dense

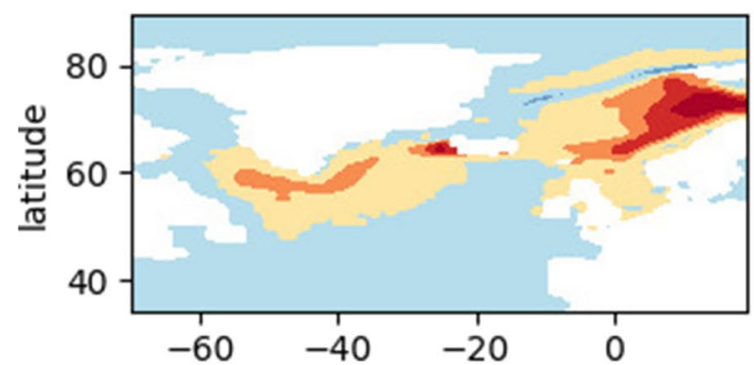

LR first decade: total

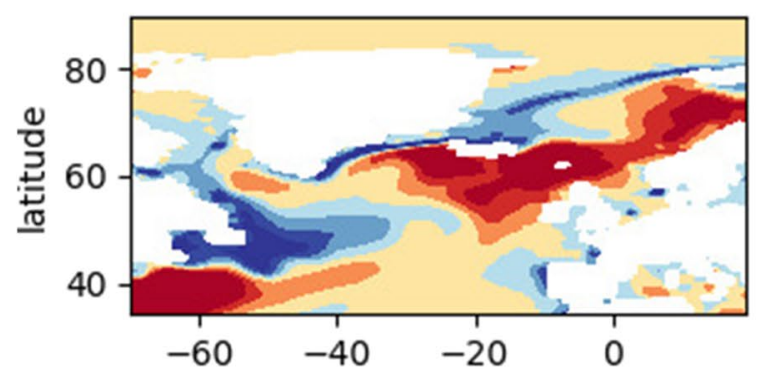

LR last decade: total

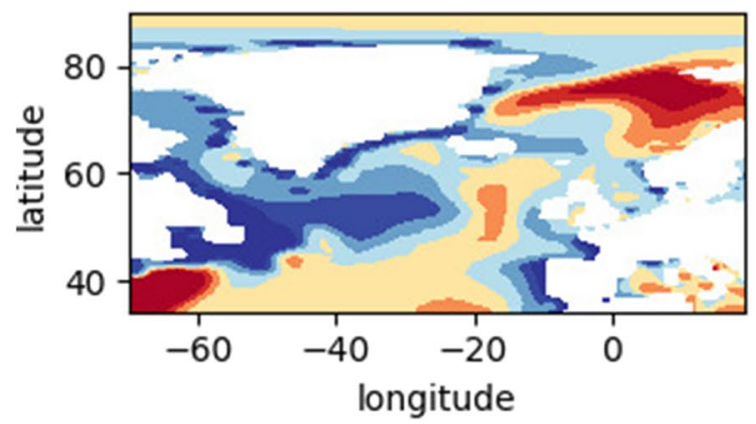

MR first decade: light

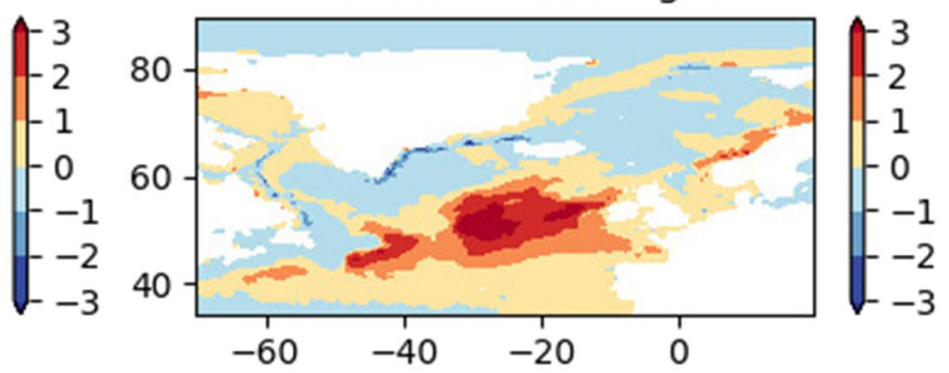

MR first decade: medium

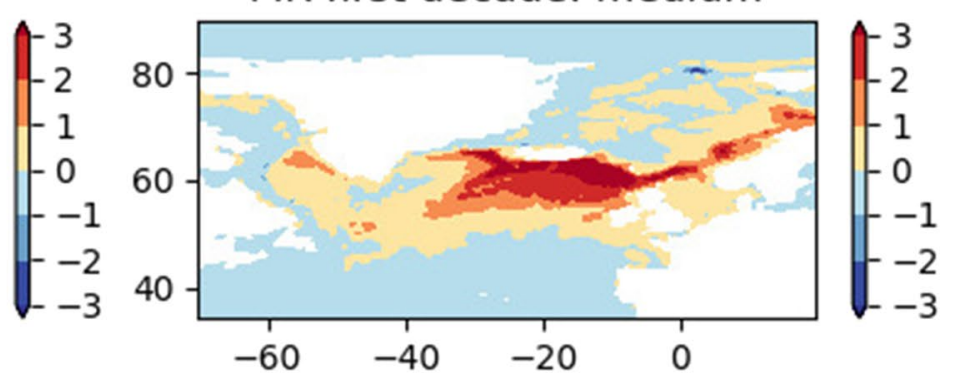

MR first decade: dense

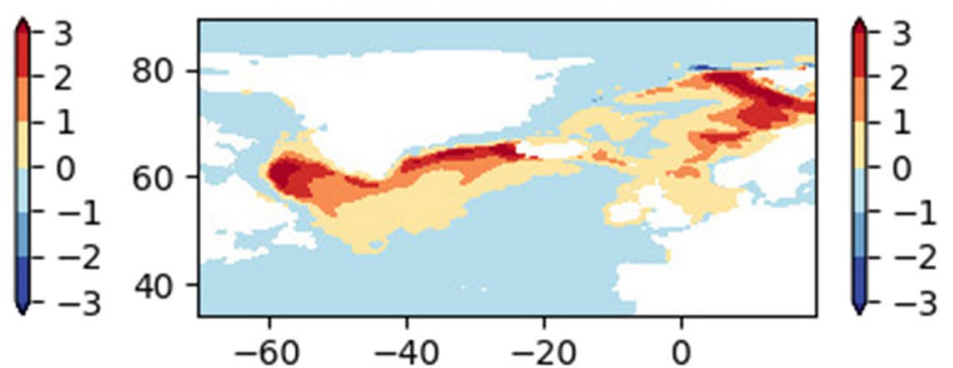

MR first decade: total

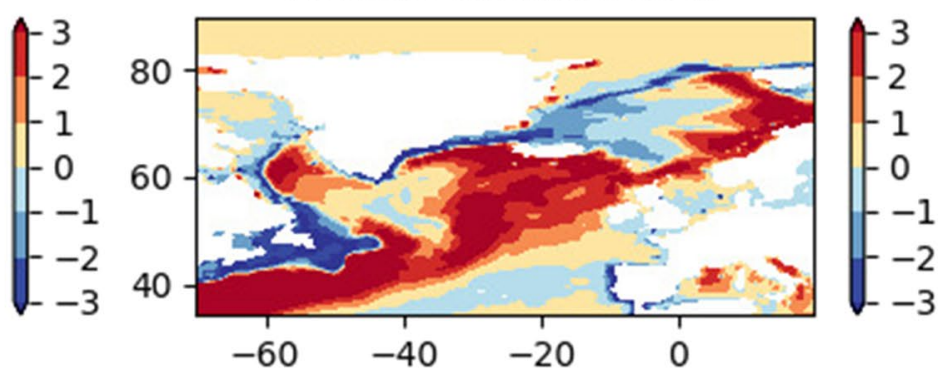

MR last decade: total
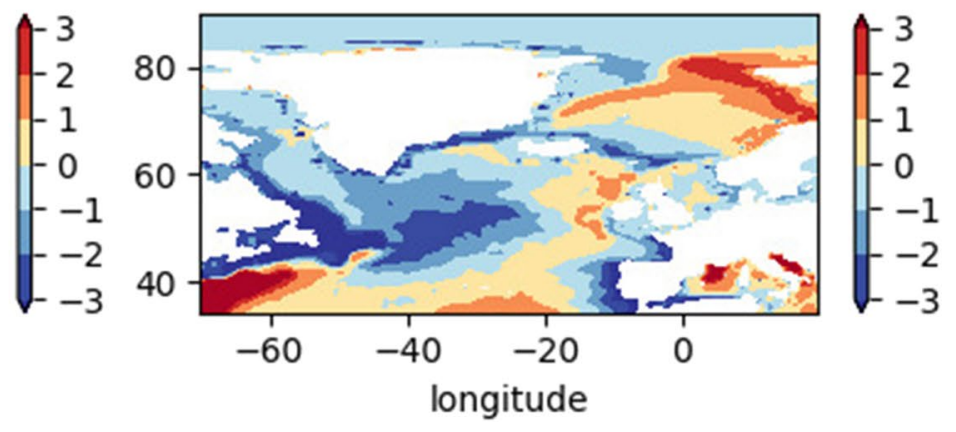
४Fig. 5 Surface buoyancy fluxes into given density surfaces. Top 4 rows are from the first decade of 1PC showing the density flux into light $\left(1026.7-1027.3 \mathrm{~kg} / \mathrm{m}^{3}\right)$, medium $\left(1027.3-1027.6 \mathrm{~kg} / \mathrm{m}^{3}\right)$, and dense $\left(1027.6-1028.2 \mathrm{~kg} / \mathrm{m}^{3}\right.$ ) density clases and the total (row 4). Last row is the total for the last decade of 1PC. Left column is LR and right column is MR

be seen from Fig. 7 where the warm and salty water of the current are located further west in MR, whereas in LR they are more concentrated along the eastern boundary. This difference in path location could influence the relative transports into the west SPG and GIN seas since the North Atlantic waters could be more readily entrained into the recirculating gyre, rather than continuing northwards into the GIN seas.

\subsection{Why do different regions respond differently to an increase in $\mathrm{CO}_{2}$ ?}

We have shown that density transformation and deep convection in the west SPG is more greatly affected by the climate change as a result of the increase in $\mathrm{CO}_{2}$ than the density transformation and deep convection in the GIN seas. As discussed in the previous section, at the end of the 1PC experiment, surface buoyancy fluxes show that there is little transformation to denser classes south of $67^{\circ} \mathrm{N}$. In the control in both models, there is a heat transport by the oceans into the subpolar North Atlantic and the GIN seas, and then the heat is lost forming denser water. With the increase in $\mathrm{CO}_{2}$ the AMOC, and meridional heat transport, weaken in both models. Hence, although both the subpolar ocean and the overlying atmosphere experience warming under increased $\mathrm{CO}_{2}$, the ocean warms less than the atmosphere, reducing the net ocean-atmosphere temperature difference in the subpolar Atlantic. The water in the west SPG therefore loses little heat to the atmosphere so there is little density transformation. In contrast, the water that enters the GIN seas can continue moving northwards until it eventually reaches a latitude where the atmosphere is cooler and heat can be lost. This leads to a shift northwards in the dense water transformation. The northwards shift of the sea ice
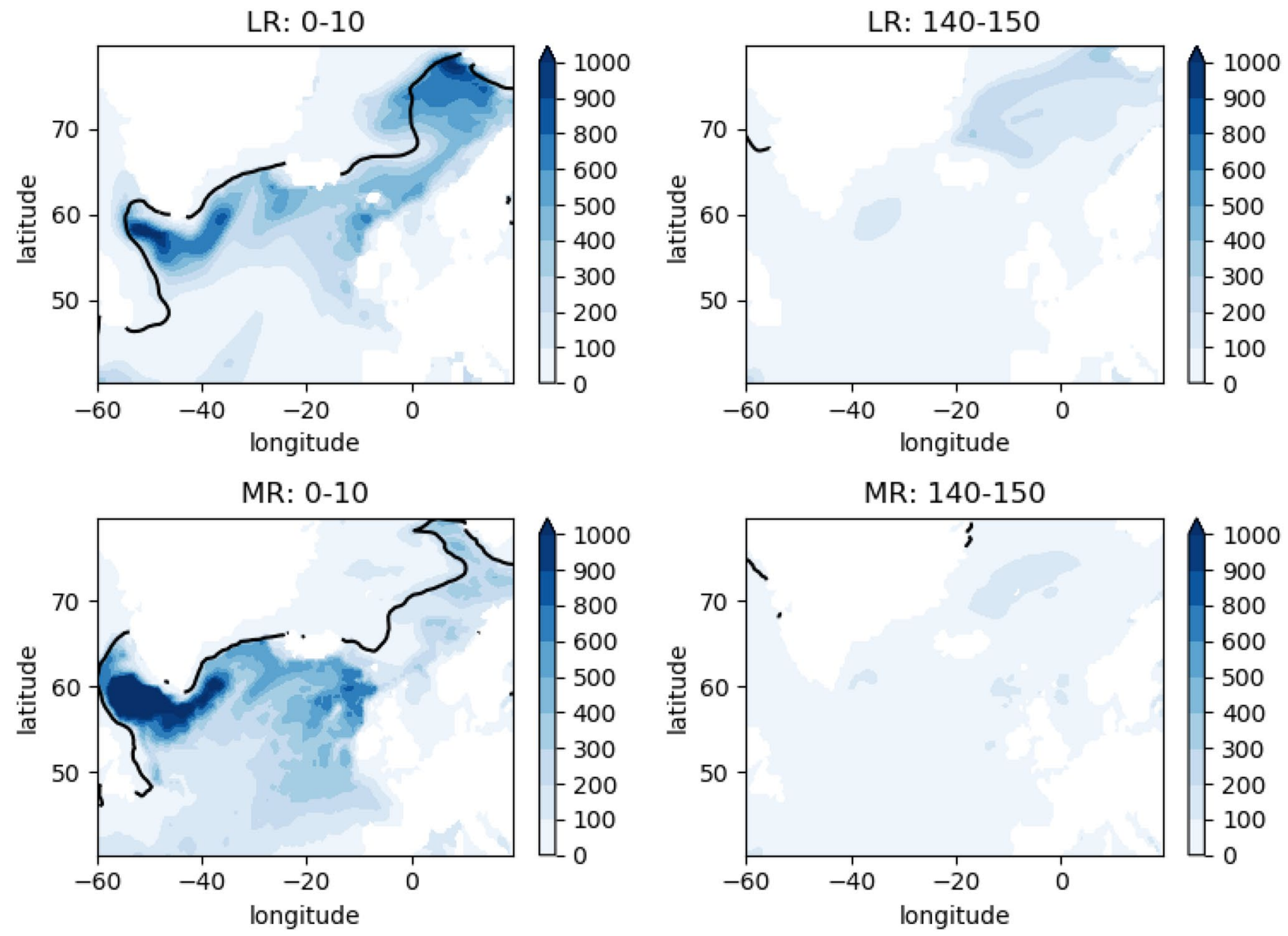

Fig. 6 Decadal means of March MLD. First decade of 1PC (left) and last decade (right) for LR (top) and MR (bottom). Black lines show the extent (defined as a concentration of 0.1) of March sea ice 

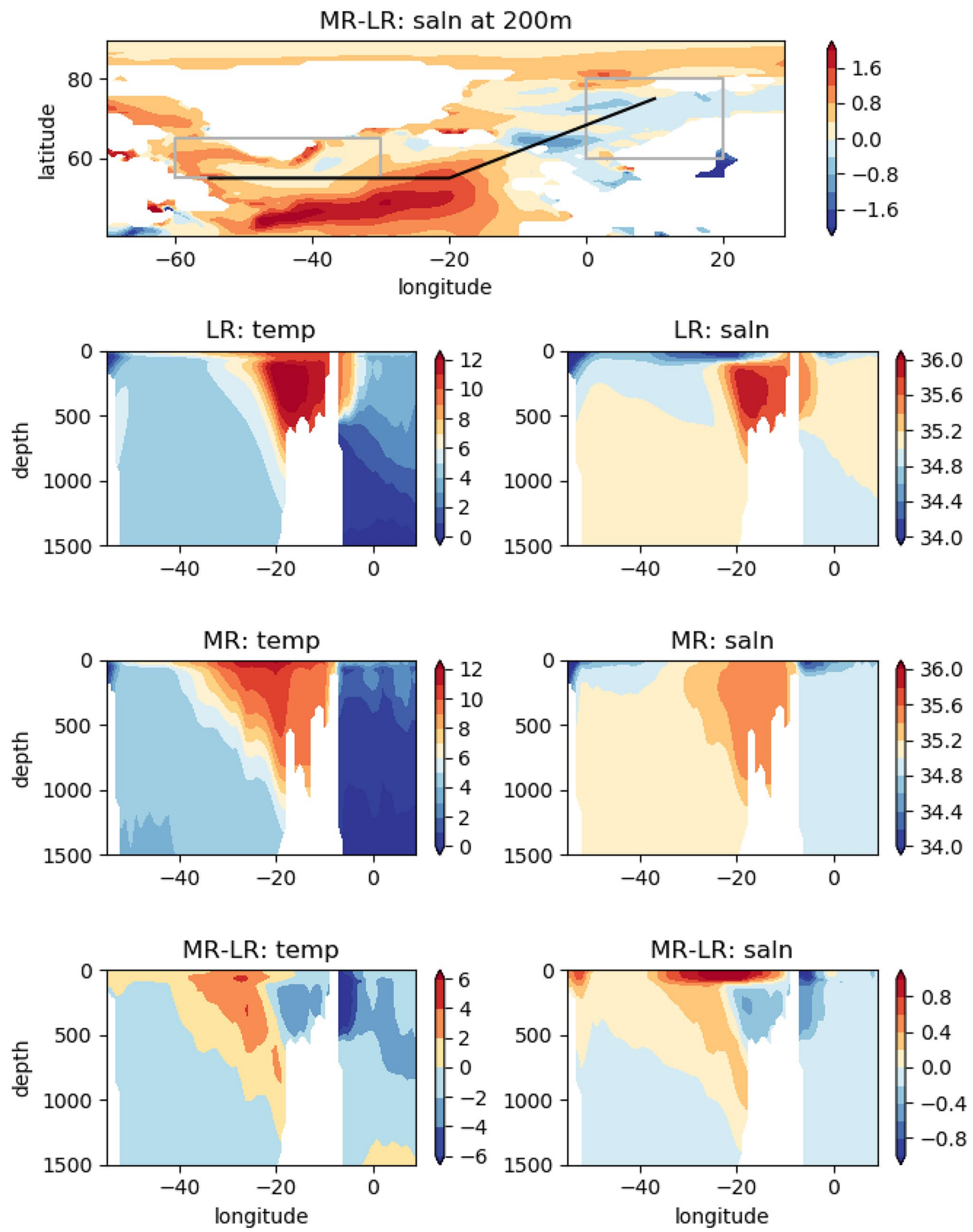

Fig. 7 Temperature and salinity along a track between the west SPG and the GIN seas (section shown by black line in top panel). Shown are LR (row 2), MR (row 3) and the difference MR-LR (row 4) for

temperature (left) and salinity (right). Top panel also shows the salinity difference between MR and LR at $200 \mathrm{~m}$ depth 

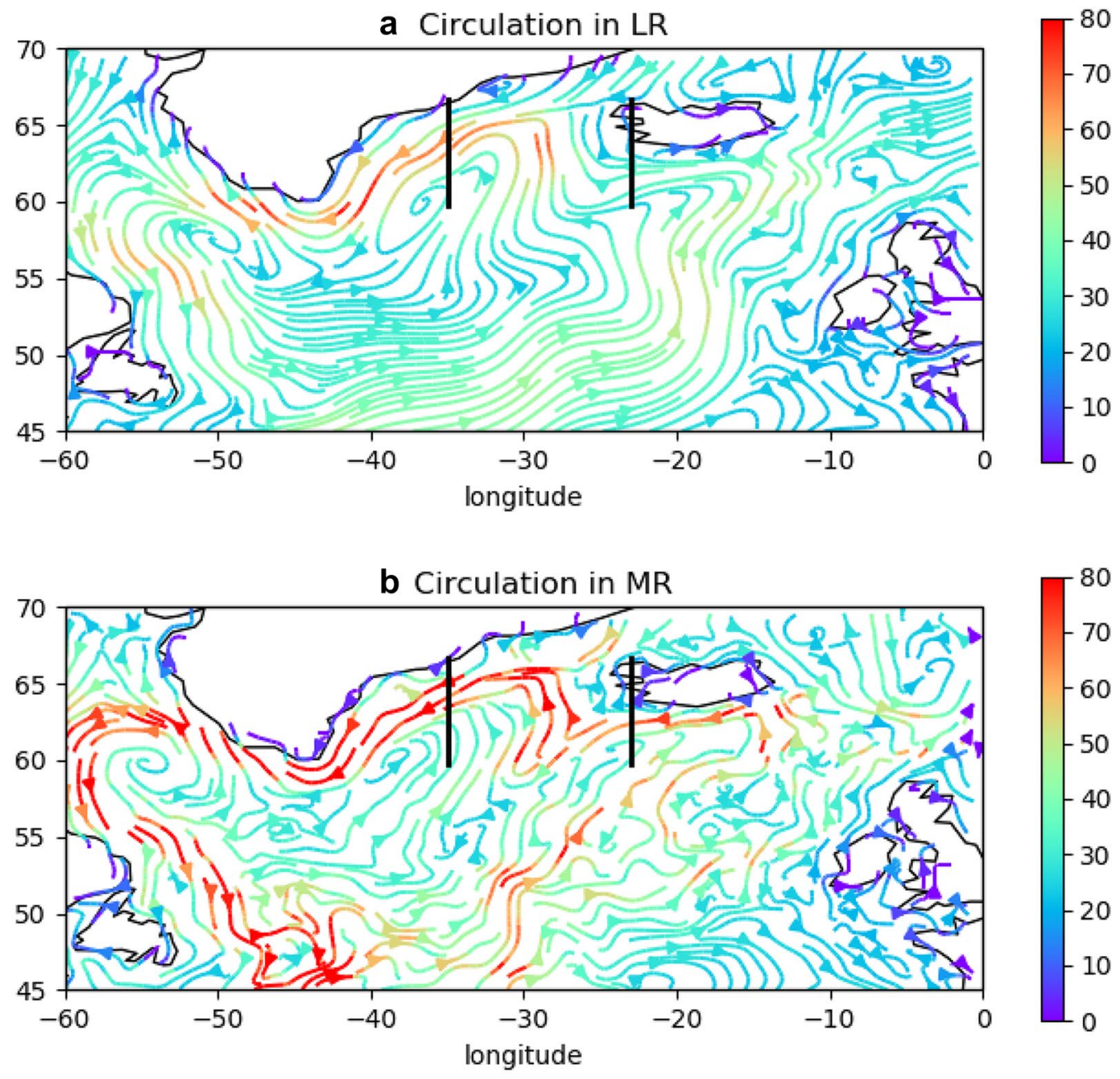

c Cumulative eastwards transport

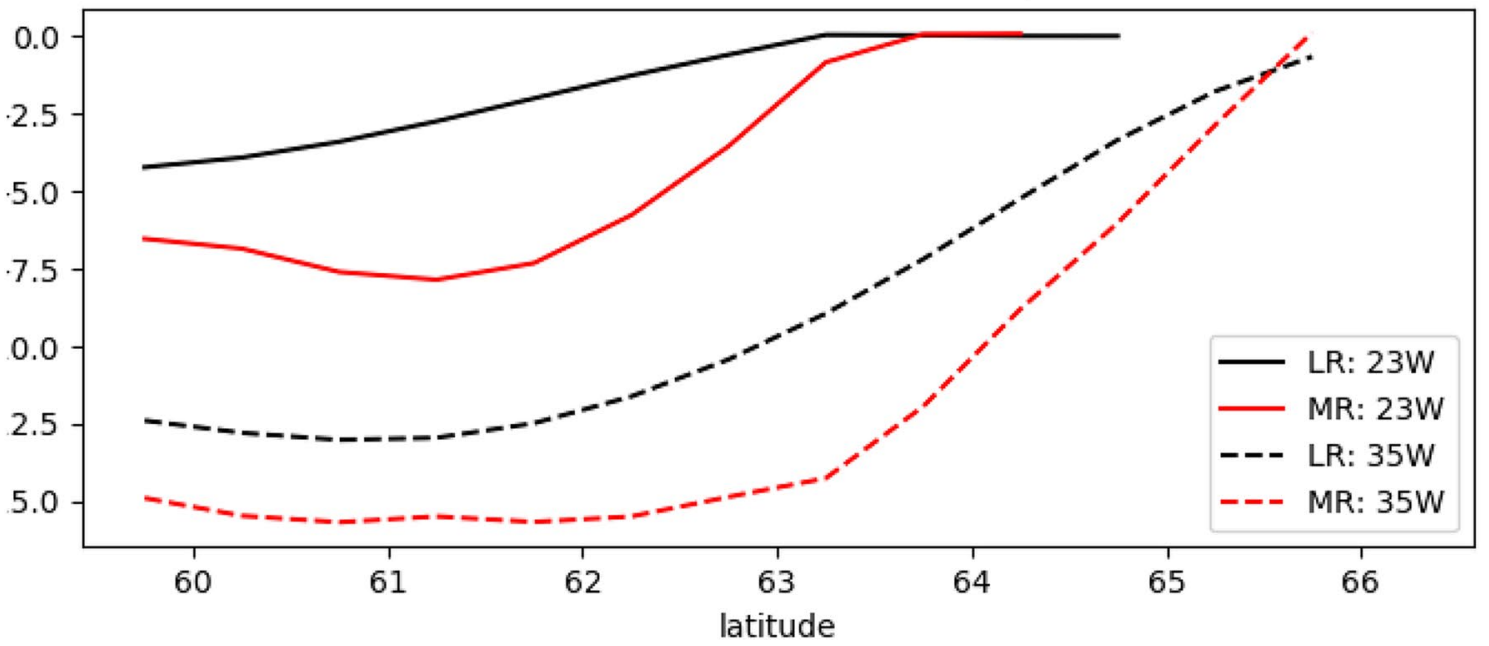

Fig. 8 Horizontal circulation of velocities integrated over the top $500 \mathrm{~m}$. a Streamlines $\left(\mathrm{m}^{2} / \mathrm{s}\right)$ for LR. b Streamlines $\left(\mathrm{m}^{2} / \mathrm{s}\right)$ for MR. c Cumulative integrals along longitude lines from north to south (Sv) at $23^{\circ} \mathrm{W}$ (solid lines) and $35^{\circ} \mathrm{W}$ (dashed lines). Black lines in $\mathbf{a}$ and $\mathbf{b}$ show sections used in c. Streamlines are curves that are tangent to the velocity vectors of the circulation 

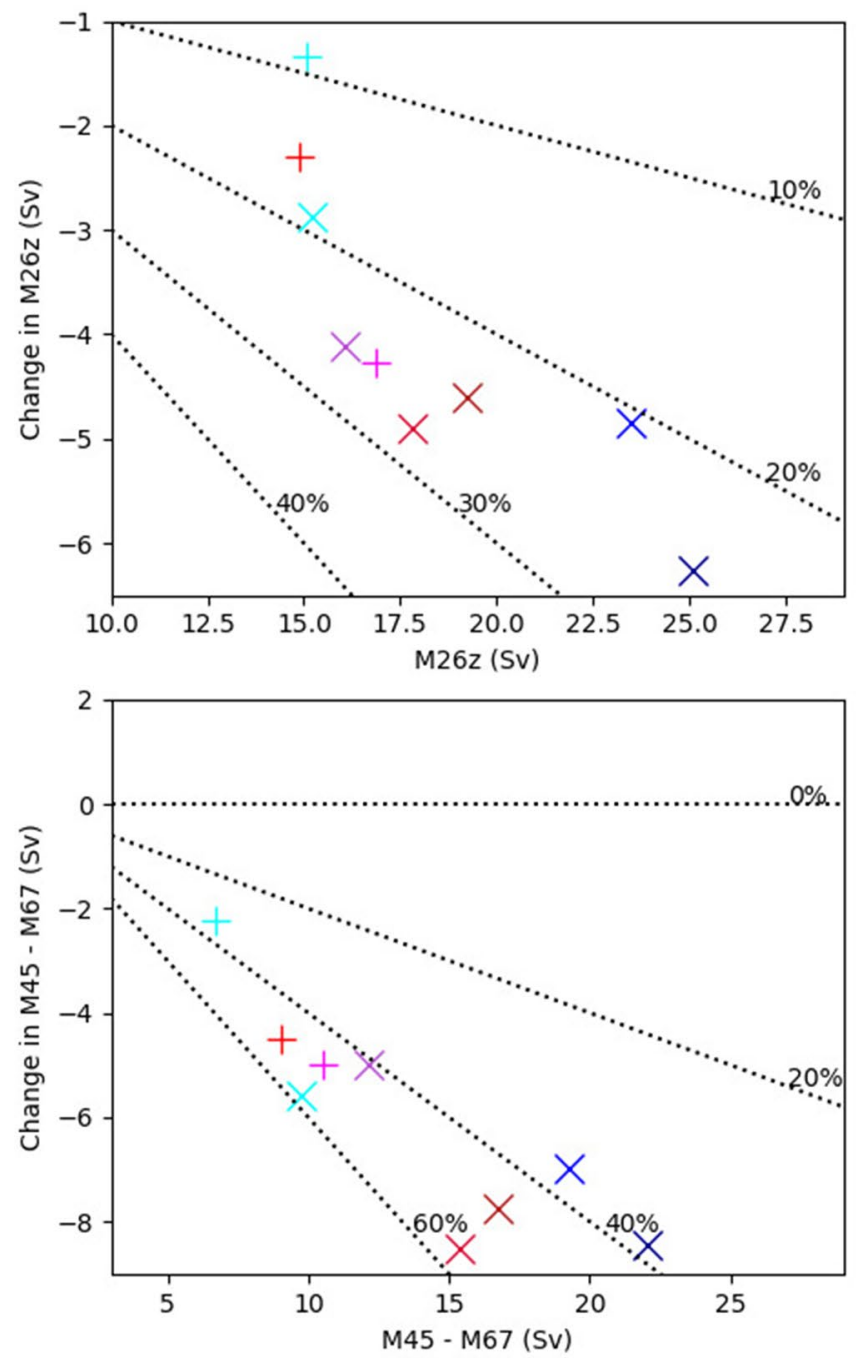

Fig. 9 Scatter plot for PRIMAVERA models showing change in AMOC strength (last 10 year mean minus 30 year mean from end of control to remove drift) versus the mean AMOC strength (mean of 150 years of control). Indices are the AMOC at $26.5^{\circ} \mathrm{N}$ in depth space, the AMOC at $45^{\circ} \mathrm{N}$ in density space, the AMOC difference

edge (Fig. 6) also allows the ocean at higher latitudes to exchange fluxes with the atmosphere. The water moving into the west SPG, on the other hand, will recirculate in the SPG and not reach higher latitudes where the atmosphere is cooler. Hence the dense water transformation in the western subpolar gyre can be switched off more easily.

In summary, we find that the two models have different paths of the North Atlantic current and strengths of the subpolar gyre, and that this may effect the mean state and the regions where dense water forms. The model (MR) with a warmer, more saline west SPG has greater surface transformation of dense water there and a greater overturning in density space south of $67^{\circ} \mathrm{N}$ (within the SPG). Both models show a cessation of dense water formation within the SPG by the end of the 1PC run (Fig. 5), and this has a greater
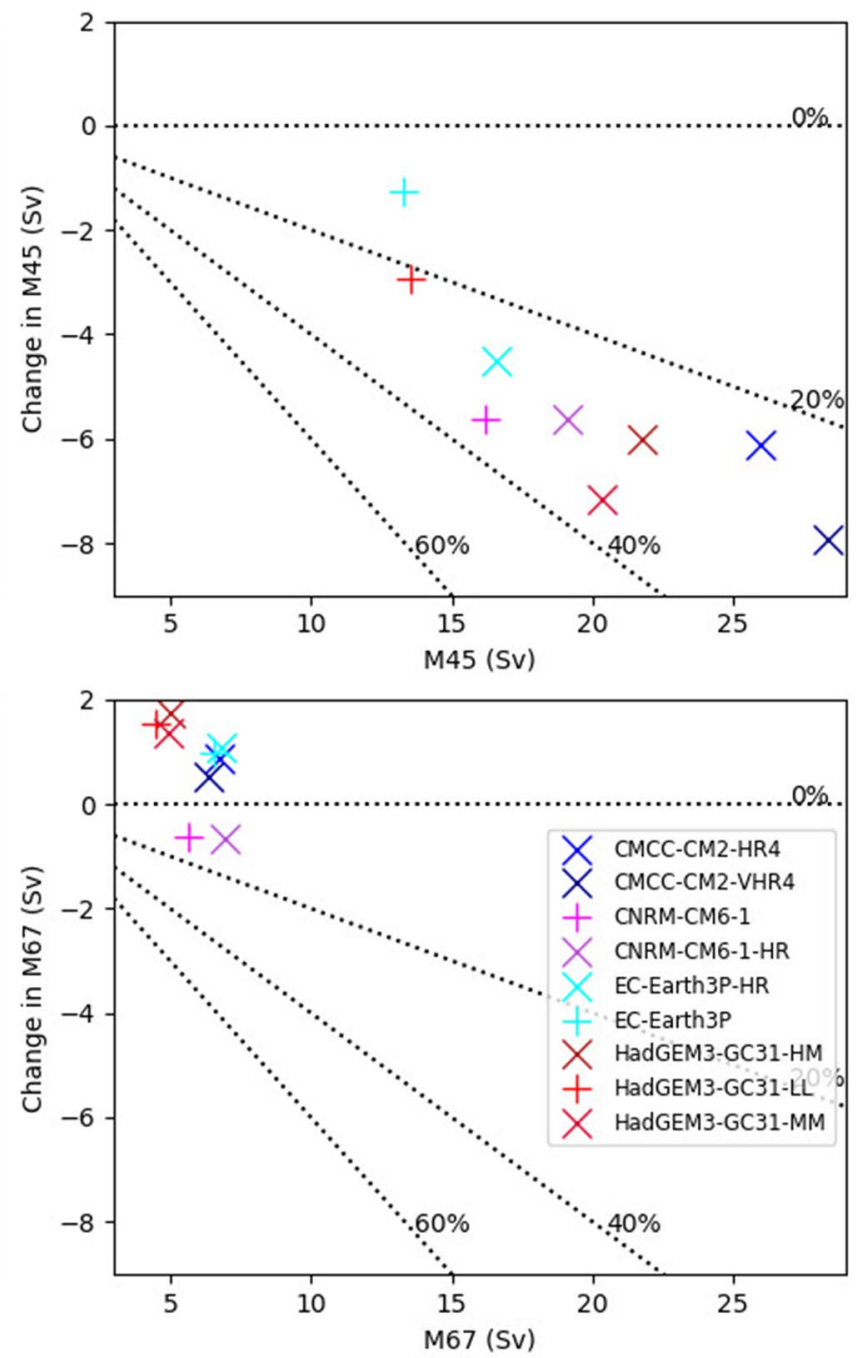

between $45^{\circ}$ and $67^{\circ} \mathrm{N}$ in density space and the AMOC at $67^{\circ} \mathrm{N}$ in density space. Symbols represent different models (see key) with resolutions equivalent to MR being represented by a 'cross' and coarser resolutions by a 'plus'

impact on MR since it has a greater fraction of its dense water formation within the SPG rather than in the GIN seas (Fig. 4).

\section{Multi-model analysis}

\subsection{Influence of the mean state}

To explore the potential for the mean state of the subpolar North Atlantic to affect weakening of the AMOC we examine the multi-model ensemble PRIMAVERA. We calculate the AMOC in depth space at $26.5^{\circ} \mathrm{N}(\mathrm{M} 26 \mathrm{z})$ and the AMOC in density space at $45^{\circ}$ and $67^{\circ} \mathrm{N}$ (M45, M67). These are shown in Fig. 9. Both M26z and M45 show that models 

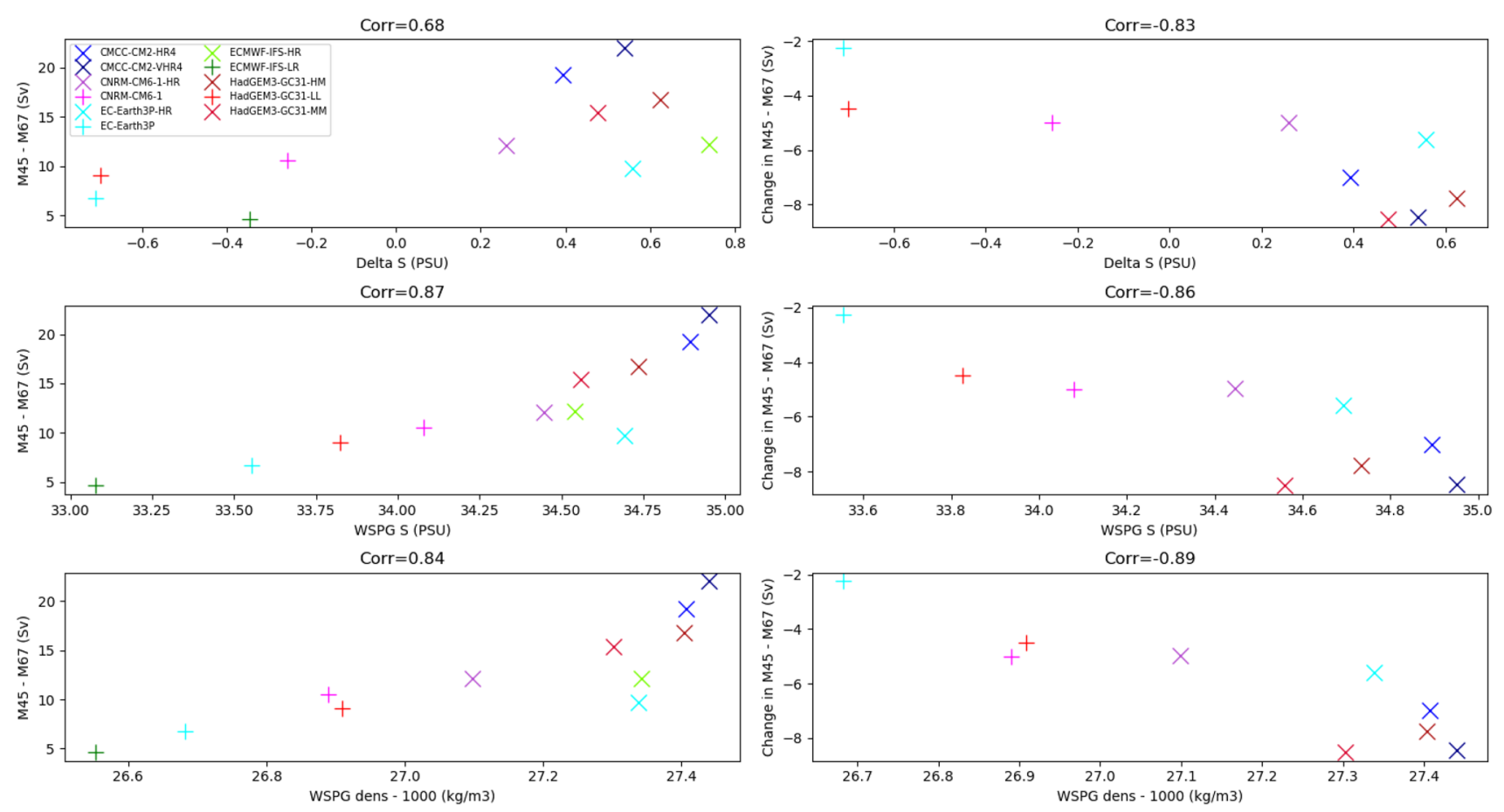

Fig. 10 Relationship of $\Delta S$ [row 1 , difference between the surface salinity in the west SPG $\left(55^{\circ}-65^{\circ} \mathrm{N}, 30^{\circ}-60^{\circ} \mathrm{W}\right)$ and eastern GIN seas $\left(60^{\circ}-80^{\circ} \mathrm{N}, 0^{\circ}-20^{\circ} \mathrm{W}\right)$ ], and west SPG salinity (row 2) and density (rows 3 ) with the mean AMOC (left) and AMOC change (right).

with a stronger $\mathrm{AMOC}$ in the control have a greater AMOC weakening, and a greater fractional AMOC weakening, in agreement with the analysis of HadGEM3-GC3.1 (though it should be noted that the scenario is different: see Sect. 2.2). M67 shows a strengthening of the AMOC in many models. This difference (a strengthening rather than the weakening found in the 1PC runs of HadGEM3-GC3.1) may be because of the different scenario, in particular could be because of changes in aerosols as well as greenhouse gases. The changes in M67 are relatively small and contribute little to the changes at M45.

To examine the potential role of the pathways to the west SPG and GIN seas, we construct an index $\Delta S$, which is the difference between the surface salinity in the west SPG $\left(55^{\circ}-65^{\circ} \mathrm{N}, 30^{\circ}-60^{\circ} \mathrm{W}\right)$ and eastern GIN seas $\left(60^{\circ}\right.$ $\left.-80^{\circ} \mathrm{N}, 0^{\circ}-20^{\circ} \mathrm{W}\right)$. See grey boxes in Fig. 7 for regions. Previous analysis has shown that the water mass properties in these regions are indicative of how much of the warm, saline subtropical Atlantic water reaches the two regions. Since much of the density transformation along the pathway is due to heat loss, we regard salinity difference as being a better indicator than temperature difference. There is some relationship between $\Delta S$ and both the AMOC magnitude $(\operatorname{corr}=0.68)$ and the amount of AMOC weakening (corr $=$ 0.83 ) in the PRIMAVERA runs, however the relationship is much stronger with the surface density or salinity in the west

Symbols represent different models (see key in Fig. 9) with resolutions equivalent to MR being represented by a 'cross' and coarser resolutions by a 'plus'

SPG itself (Fig. 10). This surface salinity depends on both the salinity of the North Atlantic current, and the proportion of North Atlantic water that reaches the west SPG region, although other processes (convection, export of fresh water from the Arctic) may also be important.

\subsection{Influence of resolution}

Figure 9 shows that those models with a low ocean resolution tend to have a weaker AMOC and a smaller AMOC reduction (both in absolute and percentage changes). They are also the models where the surface west SPG is the freshest and most buoyant (Fig. 10). Figure 11 shows the surface salinity along a section near $60^{\circ} \mathrm{N}$ (see Fig. 7 for section) and at $50^{\circ} \mathrm{N}$. The higher resolution models are more saline in the west, though there is less difference in salinity in the east and in the core of the North Atlantic current (maximum salinity in the section). This results in a smaller salinity gradient across the section and a smaller value of $\Delta S$ (Fig. 10). The higher resolution models mostly (with one exception, EC-EARTH-HR) have a more westerly location of the North Atlantic current at $50^{\circ} \mathrm{N}$. The high resolution models also have a stronger subpolar gyre strength (Fig. 11c), consistent with a multi-model study of ocean only models (Hirschi et al. 2020). These circulation differences are likely to be responsible for a greater transport of North Atlantic water 

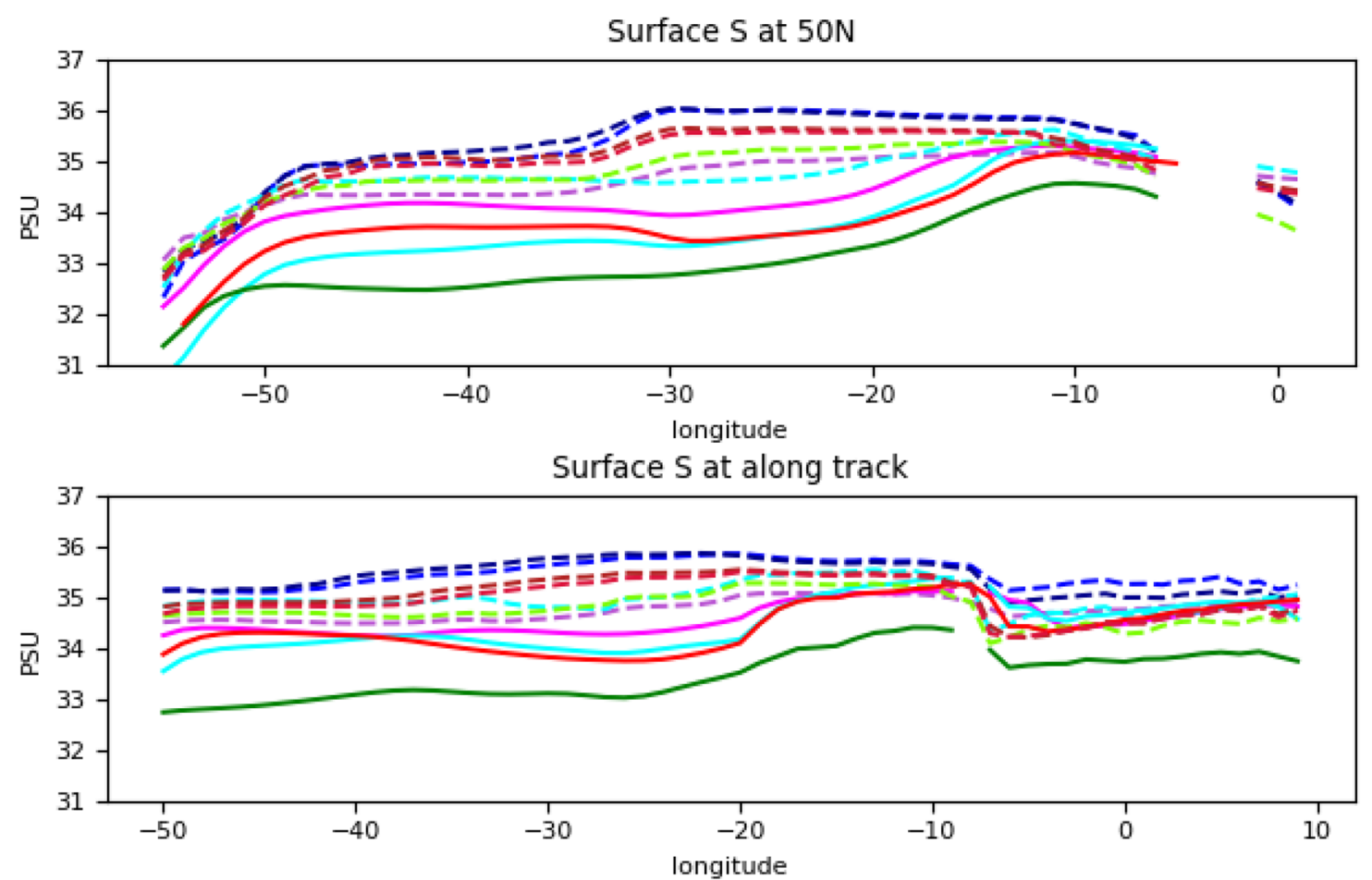

Subpolar gyre streamfunction at $58 \mathrm{~N}$

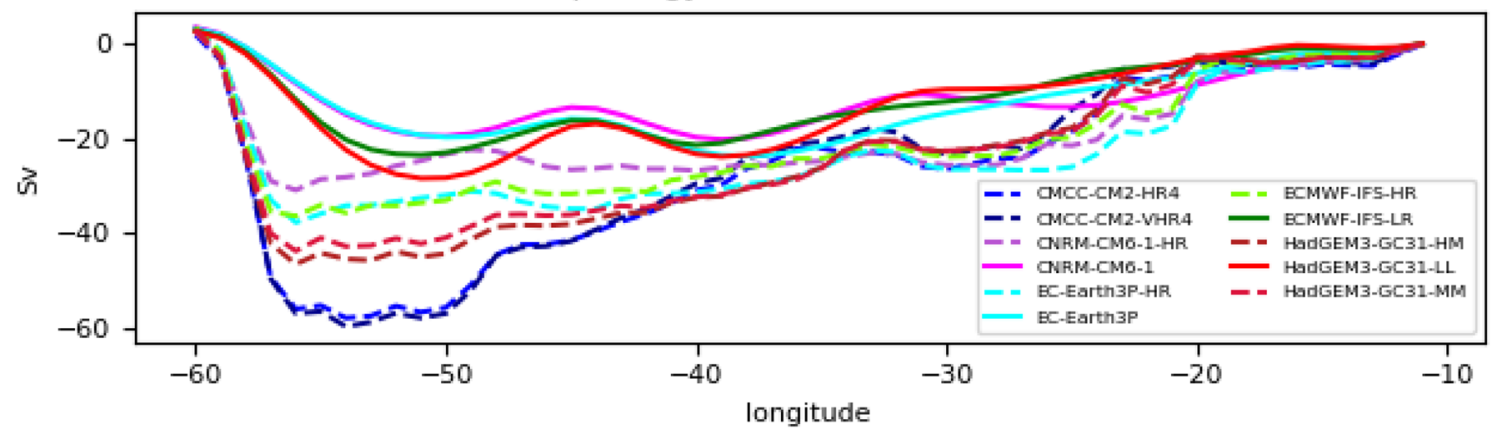

Fig. 11 Surface salinity in the control by longitude across the Atlantic at $50^{\circ} \mathrm{N}$ (top) and along the track (approximately at $60^{\circ} \mathrm{N}$ ) shown in Fig. 7 (middle). Bottom panel shows the Atlantic subpolar gyre

reaching the west SPG. Regarding the transport into the GIN seas, there is no clear resolution dependence of M67, the overturning transport into the GIN seas (Fig. 9).

Hence, the higher resolution models in this ensemble have a more saline and dense west SPG, and it is likely that this is related to the stronger transport of North Atlantic waters into the west SPG as measured by the stronger subpolar gyre. We also postulate that this is related to the more westerly North Atlantic current position (Fig. 8), though more experiments would be required to prove this. Also, we have shown that the density of the west SPG has a strong relationship with the AMOC strength (particularly the AMOC associated with dense water formation south of $67^{\circ} \mathrm{N}$ ), and that there is also a strong relationship with the subsequent amount of AMOC weakening. These results support the results found streamfunction at $58^{\circ} \mathrm{N}$. Lines represent different models in PRIMAVERA (see key) with resolutions equivalent to MR being represented by a dashed line and coarser resolutions by a solid line

in the analysis of HadGEM3-GC3.1, however the PRIMAVERA ensemble only has a few models (two of which are the two resolutions of HadGEM3-GC3.1), and all models use the NEMO ocean model (though at different versions and with different settings), although with different atmosphere and ice models. Hence these relationships may not hold in a structurally different model. Previous studies have found relationships between the temperature and salinity of the subpolar North Atlantic and the AMOC strength (Wang et al. 2014; Danabasoglu et al. 2014; Mecking et al. 2017) and between the AMOC strength and weakening (Gregory et al. 2005; Weaver et al. 2012; Winton et al. 2014). The link to resolution is less clear. In particular Sein et al. (2018) also showed a more westerly North Atlantic current position in their higher resolution models, but showed weaker AMOC 

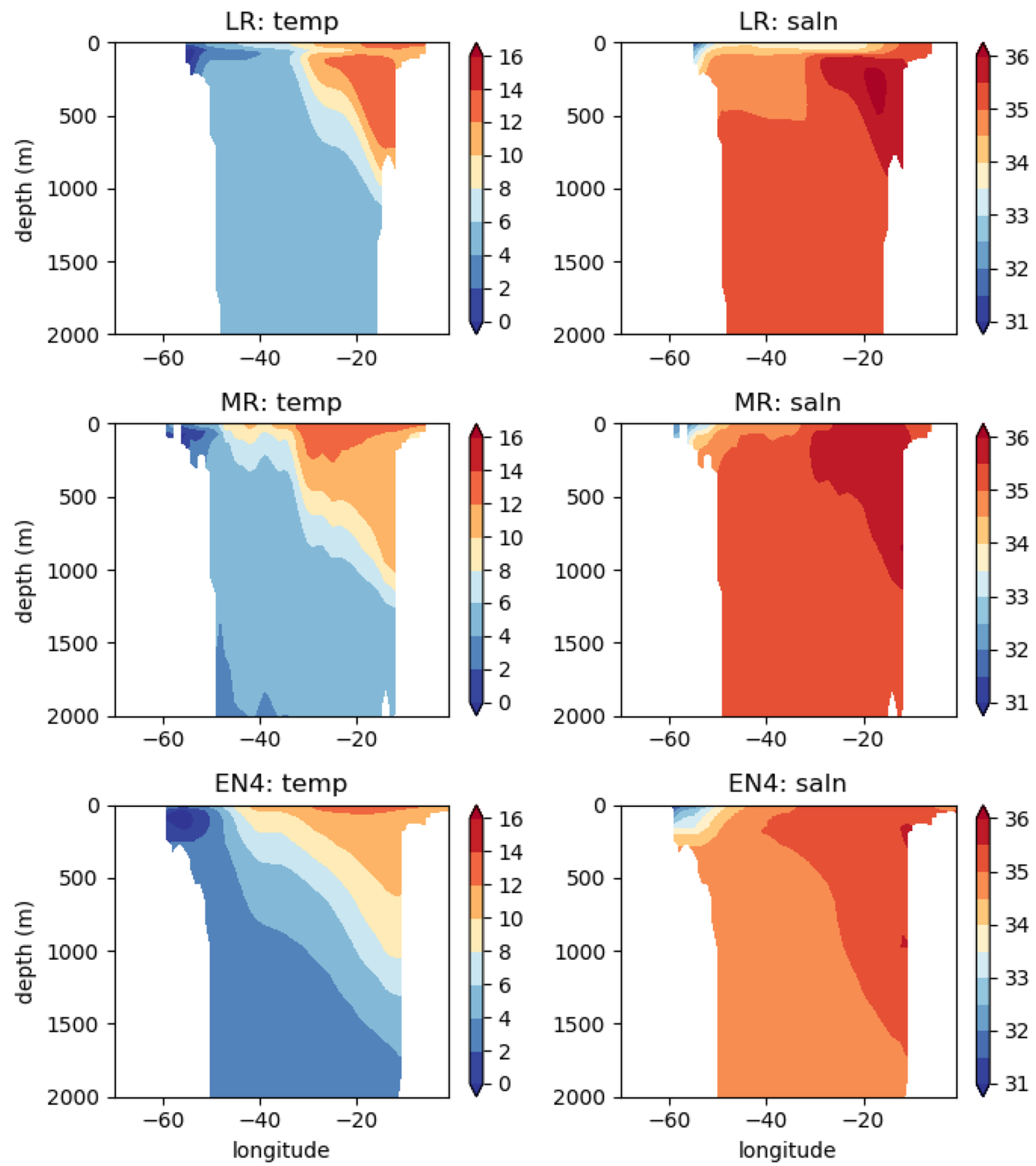

Fig. 12 Temperature and salinity at $50^{\circ} \mathrm{N}$ in CON. Shown are cross sections of temperature (left) and salinity (right) for LR (top), MR (middle) and the observational data set EN4 (bottom)

strengths. It is possible that other factors influenced the SPG salinity in that model.

\section{Comparison to observations}

The large differences in AMOC weakening in our two models have been shown to be related to the mean state. This raises the question of which model has the most realistic initial state, and hence might have the more credible projections of AMOC weakening. The control states from which the 1PC runs are initialised are run with preindustrial forcing, which would seriously limit the observations for comparison. However additional analysis with the equivalent historical simulations (not shown in every case) shows that the differences between the models and between models and observations are much larger than the difference between each model's preindustrial and recent historical periods.

Comparison with sections (Figs. 12, 13) show that although both models are warmer and saltier than the 

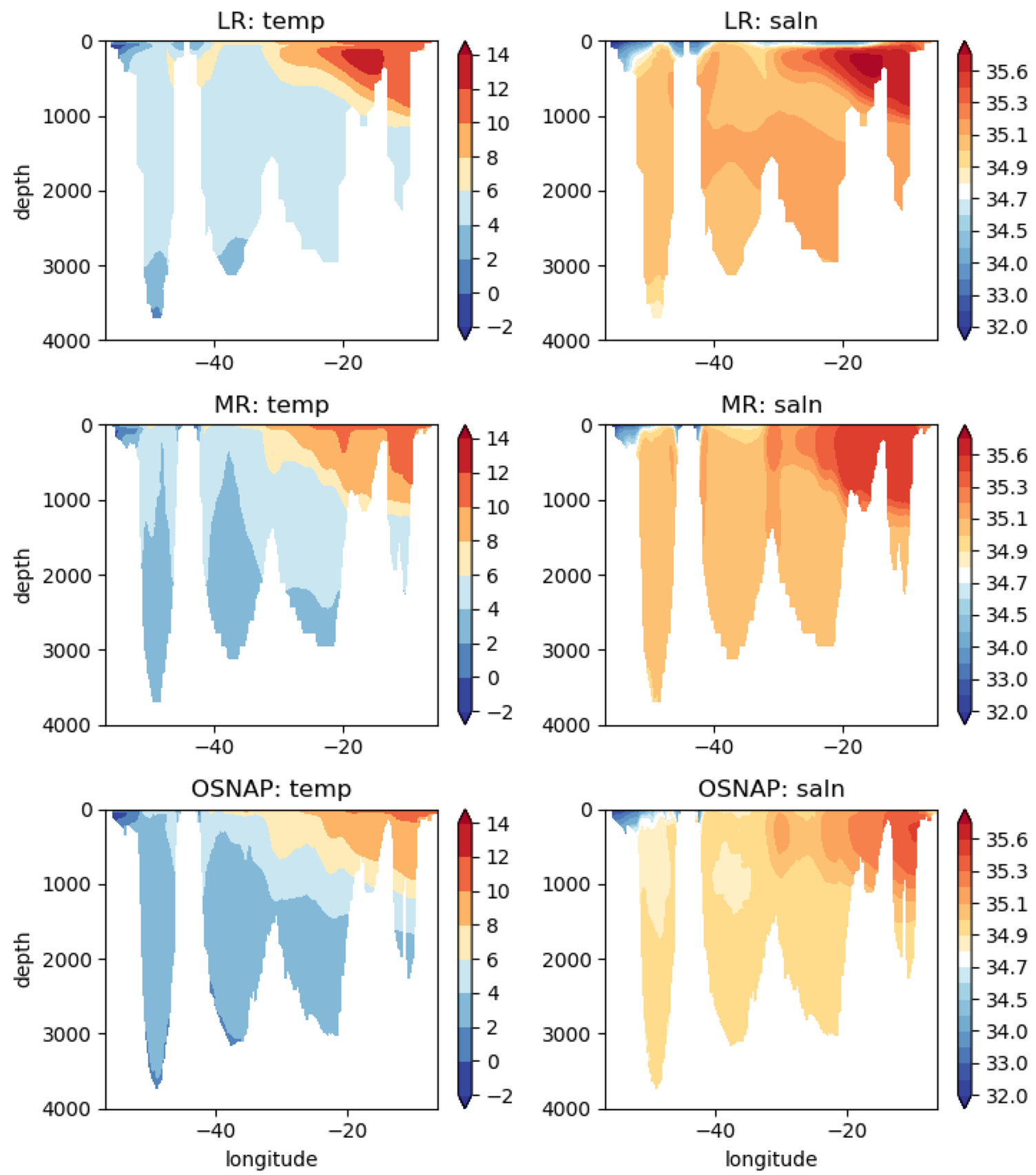

Fig. 13 Temperature and salinity along the OSNAP section in CON. Shown are cross sections of temperature (left) and salinity (right) for LR (top), MR (middle) and the OSNAP observational dataset (bottom)

observations, the biases are generally reduced in MR. In particular MR has a better (more westerly) position of the North Atlantic current in Fig. 12, and doesn't have the cold, fresh surface anomaly, with a subsurface increase in temperature and salinity seen in the easterly SPG of LR.

Surface fields (Fig. 14) also show a clear improvement of MR over LR within much of the subtropical and subpolar North Atlantic. Both models show biases in the GIN seas: too salty along the coast of Norway, and too cold and fresh over much of the GIN seas. However, in the west SPG, the results are less clear. Maps of surface fields show that MR is too warm and salty in the Labrador Sea, part of the west SPG, though has a good agreement over the Irminger Sea. LR has a better salinity field in the Labrador Sea, though is too cold and fresh near the subtropical/subpolar gyre boundary. Surface biases are generally 

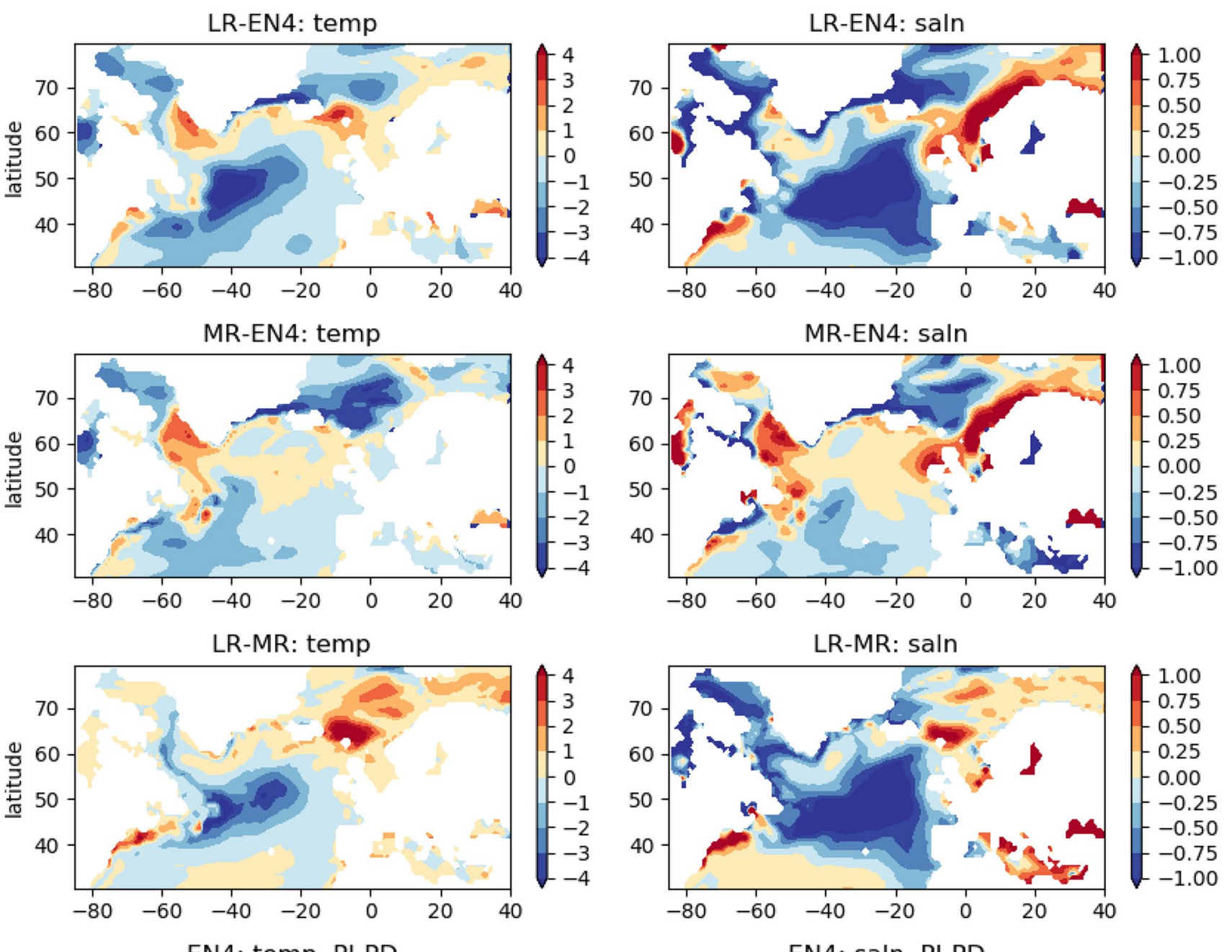

EN4: temp, PI-PD

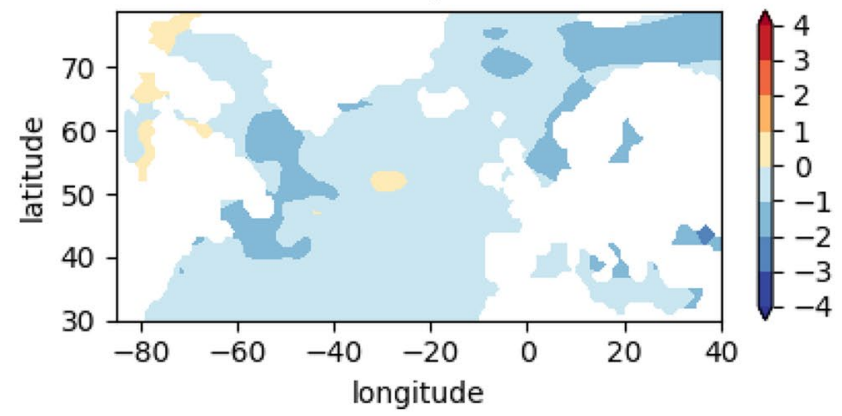

Fig. 14 Surface temperature (left) and salinity (right). The top rows show the difference of CON in LR and MR from EN4 over the preindustrial period. The third row shows the difference between MR and

reduced in LR, however the stratification (and profiles of temperature and salinity) is better in MR (Fig. 15). These results support our findings that MR has a greater influence of warm, saline waters on the west SPG, but are unclear whether this is supported by the observations. Treguier et al. (2005) found that the models in their study

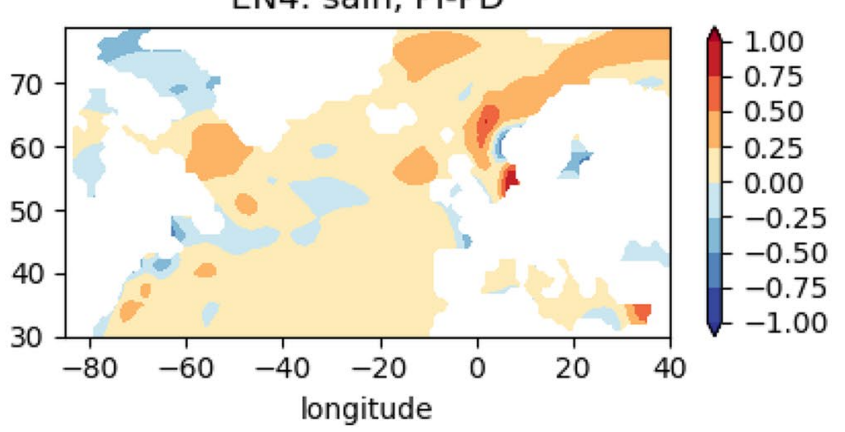

LR and the last row shows the difference between the preindustrial period (1900-1950) and the present day (2000-2014) in EN4

(which were all of higher resolution than this study), may have overestimated the salt transport around and across the Reykjanes ridge.

Comparison with AMOC profiles shows both models are too weak and shallow at $26.5^{\circ} \mathrm{N}$, though MR is slightly improved (Fig. 16). We also show the overturning in density 

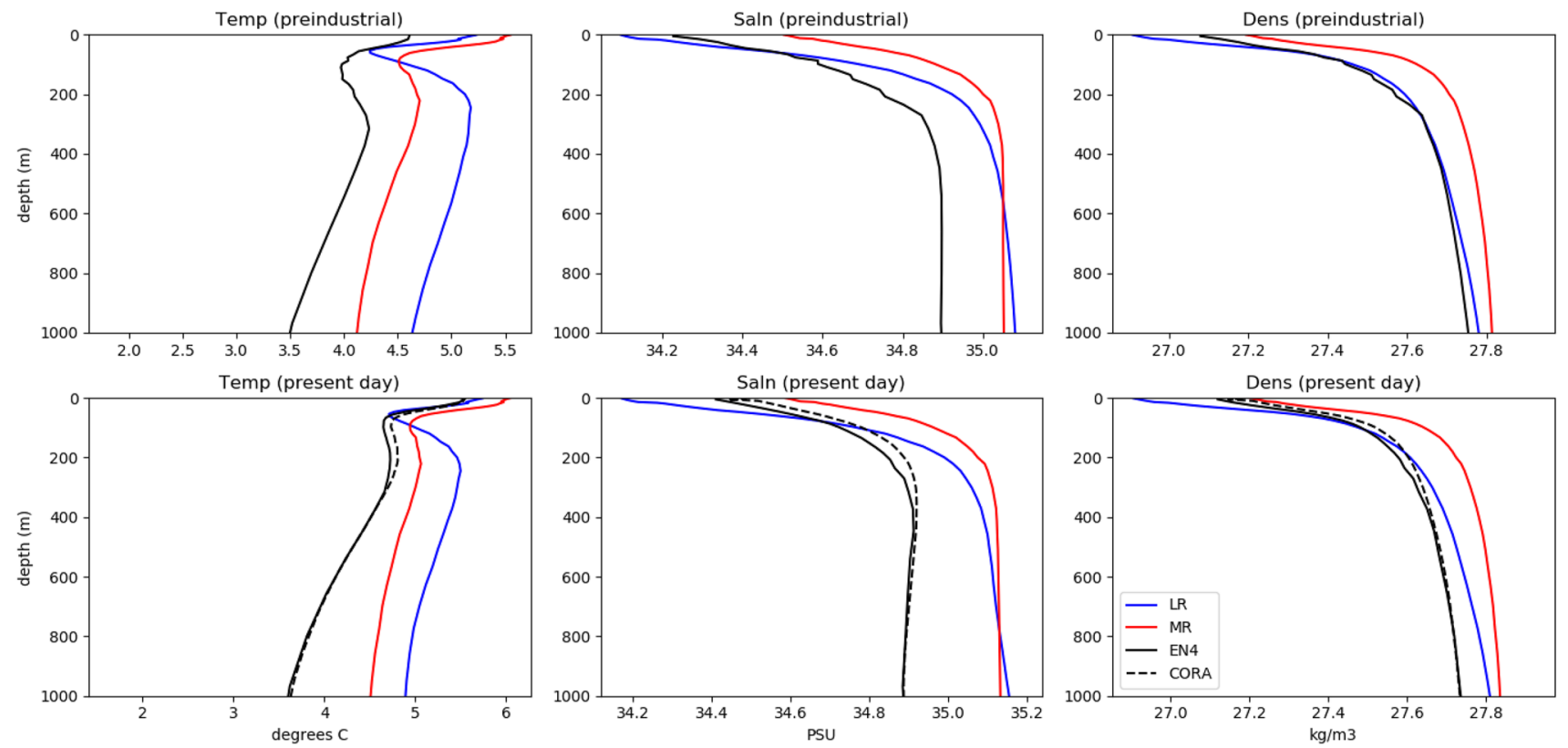

Fig. 15 Profiles of temperature, salinity and density over the west SPG $\left(55^{\circ}-60^{\circ} \mathrm{N}, 52^{\circ}-57^{\circ} \mathrm{W}\right)$ for preindustrial (top) and present day (bottom). Profiles are for the MR and LR models as well as EN4 and CORA observational data sets
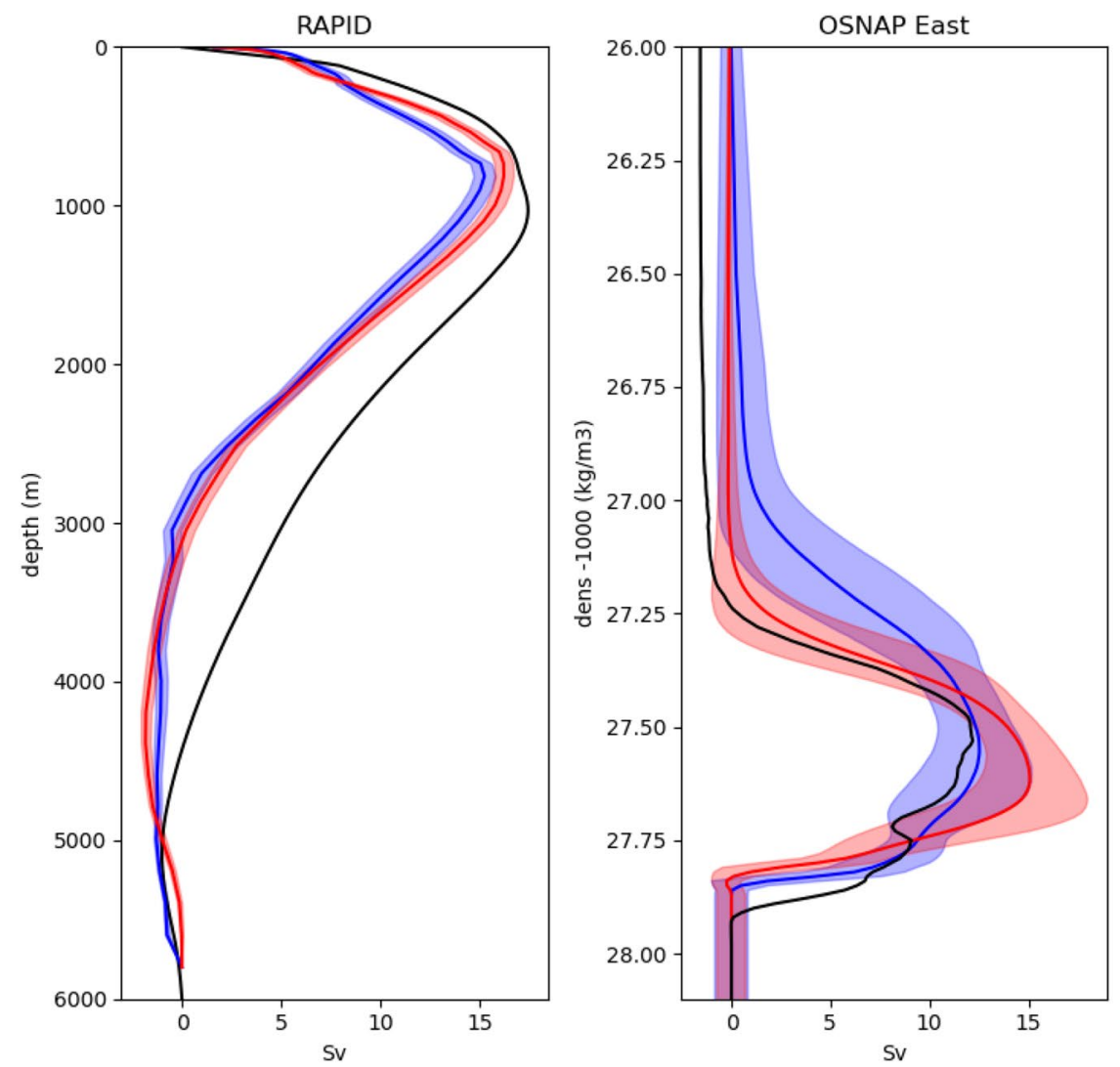

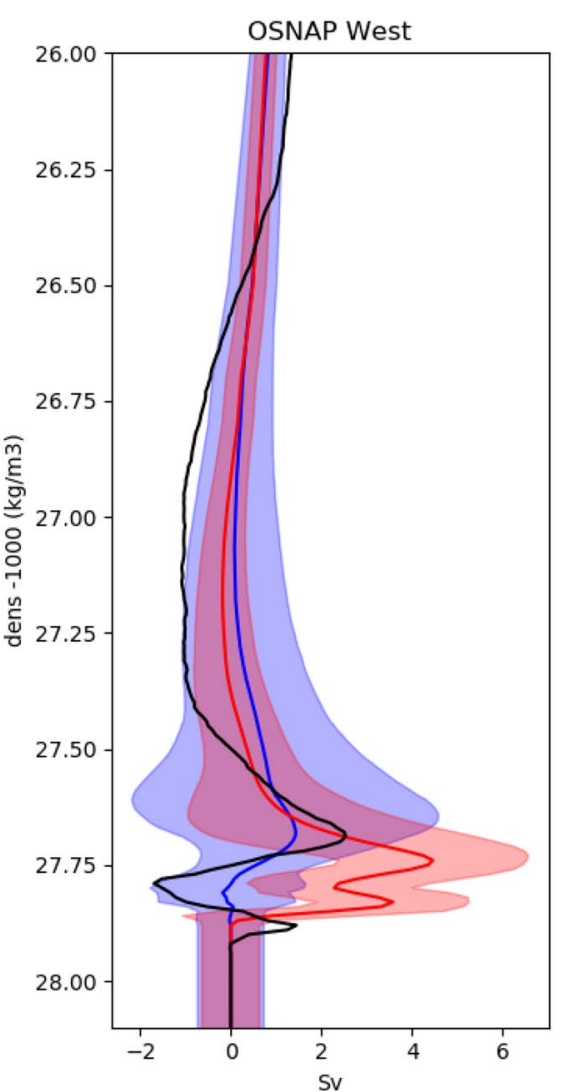

Fig. 16 Comparison of streamfunctions with RAPID observations in depth space at $26.5^{\circ} \mathrm{N}$ (left) and OSNAP observations in density space at $55^{\circ}-60^{\circ} \mathrm{N}$ across the east section (middle) and west section (right). Shown are LR (blue), MR (red) and observations (black).
Shaded regions show the model spread (twice the standard deviation) of profiles that are averaged over the length of the observational record (14 years for RAPID and 21 months for OSNAP) 
space across a section in the SPG for comparison with observations (Lozier et al. 2017). This can also be split into two sections: the overturning across the western section (Labrador sea) and the overturning across the eastern section (between Greenland and Scotland. The AMOC in LR has a better magnitude of overturning in both sections and a better density of the maximum overturning in the western section. Zou et al. (2020) suggest that salinity biases in the Labrador Sea can affect the overturning in density space across the western section. We do see some differences which might be related to the salinity biases, however both models agree reasonably well with the observations of overturning in both sections, including that the overturning in the Labrador Sea is weak.

Another AMOC-related metric that can be compared to observations is mixed layer depths. These are a proxy for deep convection and are related to the AMOC strength (Spall 2004). Figure 6 shows March mixed layer depths from the two resolutions. In both resolutions the mixed layer depths in the west SPG are too deep [observations show climatological mixed layer depths of less than $1000 \mathrm{~m}$ (de Boyer Montégut et al. 2004)], however MR has a greater bias. Having too deep a mixed layer in the west SPG is a common bias among climate models (Heuze 2017), however this bias may be worse in models with a higher horizontal ocean resolution (Koenigk et al. 2020).

Although the higher resolution model (MR) performs better at some aspects of the North Atlantic circulation, in particular the location of the North Atlantic current, in other aspects, such as the properties in the west SPG and the OSNAP strengths, the lower resolution model (LR) performs better. The improvement of the North Atlantic current path could degrade the properties in the west SPG if it is compensating for other errors in circulation or atmospheric interactions. Climate models have difficulty resolving many processes in the subpolar gyre, even at high resolution (Treguier et al. 2005; Fox-Kemper et al. 2019). The west SPG is a region where cold, fresh Arctic waters meet the warm, saline Atlantic waters and where dense water transformation and deep convection occur, so model deficiencies in representing fresh coastal regions, transports through narrow straits, overflows and sinking could result in temperature and salinity biases. One aspect that is different in the two resolutions is the parameterisation of mixing by eddies: it is parameterised in LR, however in MR eddies are starting to be resolved and it is unclear whether parameterised mixing should be included as well (Hewitt et al. 2017). In HadGEM3-GC3.1 parameterisations were not included for MR, however they are included for some of the PRIMAVERA models with the same resolution and this does not appear to have a significant impact on the AMOC. We note that Winton et al. (2014) found that different eddy parameterisations affected the AMOC strength and hence the rate of AMOC weakening.

\section{Conclusions}

We have shown that the AMOC in HadGEM3-GC3.1 is stronger and has a greater weakening in response to increases in greenhouse gases in the model with higher resolution. Differences in the mean state are associated with the formation of deep water and convection in different regions: our results suggest that models with a greater advection of warm, saline water into the west SPG experience a greater heat loss there and hence a greater formation of deep waters. When there is an increase in $\mathrm{CO}_{2}$, the atmosphere warms and ocean cools (because of a reduction in heat transport as the AMOC weakens), leading to less heat loss from the ocean which can eventually shut down the formation of deep water there. In models where there is more deep water formation in the GIN seas, the cooler waters associated with a weakening AMOC can move northwards until they reach a latitude where the atmosphere is cooler and heat loss (and deep water formation) can occur. The relationship between the mean state and AMOC strength has been found in other studies (Wang et al. 2014; Danabasoglu et al. 2014; Mecking et al. 2017) and the relationship between AMOC strength and weakening has also been described (Gregory et al. 2005; Weaver et al. 2012; Winton et al. 2014). Previous studies have also found a greater sensitivity to increasing $\mathrm{CO}_{2}$ of the sinking in the SPG than the GIN seas (Wood et al. 1999; Brodeau and Koenigk 2016).

We also find some influence of the horizontal ocean resolution on the mean state, and hence on the AMOC weakening. Models with a higher (eddy-permitting) resolution generally have a stronger subpolar gyre and an improved path of the Gulf Stream and North Atlantic current, though there may still be deficiencies at eddy-permitting resolution (Chassignet and Marshall 2008; Scaife et al. 2011). These differences in circulation appear to result in a stronger influence of subtropical waters on the west SPG. In the ensemble of models examined, those with a higher resolution have a more saline and dense west SPG, a stronger AMOC and a greater AMOC weakening. Other studies have shown higher resolution models having a stronger AMOC (Roberts et al. 2016, 2019a; Sein et al. 2018; Menary et al. 2018; Docquier et al. 2019; Hirschi et al. 2020), however most of these studies (and all of the models in this study) have used the same ocean submodel (NEMO). Some other modelling studies have come to the opposite conclusion (Yokohata et al. 2007; Delworth et al. 2012; Winton et al. 2014). In particular Winton et al. (2014) found that, although there was greater AMOC weakening in their lower resolution model, the weakening was primarily affected by the mean state, and that changes in eddy parameterisations could significantly change the mean state and hence the AMOC weakening. Hence it is likely that, even if there is some influence of ocean resolution on the mean state of the subpolar North Atlantic, there are other factors 
that affect the mean state, and hence the AMOC response to increasing greenhouse gases.

Winton et al. (2014) also found that higher resolution models had a stronger AMOC and a greater transient climate response (TCR). In MR and LR there is a slight difference in TCR (2.5 and $2.7^{\circ} \mathrm{C}$ respectively) although the equilibrium climate sensitivity is similar (Andrews et al. 2019). The slight difference found here is consistent with the relatively small difference between AMOC states compared to those in Winton et al. (2014).

Further research is required to understand the sensitivity of the AMOC to resolution and the mean state in a wider range of climate models. Climate models have different biases in their mean state (Flato et al. 2013), so a greater understanding of which aspects of the biases are the most important for the AMOC could help us to reduce the uncertainty in future AMOC projections and to target processes for model development.

Acknowledgements LJ, MR, DI, TK, VM, CR, YR-R were funded by the PRIMAVERA project, funded by the European Union's Horizon 2020 programme under grant agreement 641727 . LJ, HH, MR, RW were supported by the Met Office Hadley Centre Climate Programme funded by BEIS and Defra (GA01101). We wish to thank two anonymous reviewers for their comments which improved this manuscript.

Open Access This article is licensed under a Creative Commons Attribution 4.0 International License, which permits use, sharing, adaptation, distribution and reproduction in any medium or format, as long as you give appropriate credit to the original author(s) and the source, provide a link to the Creative Commons licence, and indicate if changes were made. The images or other third party material in this article are included in the article's Creative Commons licence, unless indicated otherwise in a credit line to the material. If material is not included in the article's Creative Commons licence and your intended use is not permitted by statutory regulation or exceeds the permitted use, you will need to obtain permission directly from the copyright holder. To view a copy of this licence, visit http://creativecommons.org/licenses/by/4.0/.

\section{Appendix}

Following Marsh (2000), if we assume a steady state and incompressibility, then the density transformation across a given density $\rho$ north of a latitude, must be equal to the export of waters denser than $\rho$ southwards by the overturning in density space. Hence a streamfunction at a given latitude can be calculated from the density transformation north of that latitude. The main component of that density transformation is surface buoyancy forcing (from surface heat and freshwater flux), with smaller contributions from diapycnal diffusion and density changes along isopycnals (cabbelling). We neglect these smaller changes and calculate an implied overturning from surface buoyancy forcing alone. We note that in the 1PC experiments the ocean state is evolving and not in steady state. Hence the overturning circulation may not have time to adjust completely to the density transformations. However, previous studies (Grist et al. 2009, 2012) found good agreement between the two at decadal timescales when examing variability.

We first calculate the surface buoyancy flux $B=B_{h}+B_{s}$ :

$B_{h}=-\alpha \frac{Q}{C p}$

$B_{s}=-\beta \frac{\rho s W}{1-s}$

where $Q$ is the surface heat flux, $C p$ the specific heat capacity of water, $\rho$ the surface density, $s$ the non-dimensional surface salinity and $W$ the surface fresh water flux (from precipitation, evaporation, runoff and ice processes). The two parameters $\alpha$ and $\beta$ are the thermal and haline expansion coefficients and are calculated from the gradient of density with respect to temperature and salinity at each grid point. See Josey et al. (2009) for more details.

From the surface buoyancy flux we calculate the area integrated surface buoyancy flux $\left(B_{i n}(L, \rho)\right)$ north of the latitude $L$ and where the isopycnal $\rho$ outcrops. Then calculate the overturning at this latitude implied by the buoyancy fluxes

$F(L, \rho)=\frac{\partial B_{i n}(L, \rho)}{\partial \rho}$

The method is described in more detail in Marsh (2000) and Josey et al. (2009).

\section{References}

Andrews T, Andrews MB, Bodas-Salcedo A, Jones GS, Kuhlbrodt T, Manners J, Menary MB, Ridley J, Ringer MA, Sellar AA, Senior CA, Tang Y (2019) Forcings, feedbacks, and climate sensitivity in hadgem3-gc3.1 and ukesm1. J Adv Model Earth Syst 11:43774394. https://doi.org/10.1029/2019MS001866

Brodeau L, Koenigk T (2016) Extinction of the northern oceanic deep convection in an ensemble of climate model simulations of the 20th and 21st centuries. Clim Dyn 46(9):2863-2882. https://doi. org/10.1007/s00382-015-2736-5

Buckley MW, Marshall J (2016) Observations, inferences, and mechanisms of the Atlantic Meridional Overturning Circulation: a review. Rev Geophys 54(1):2015RG000,493+. https://doi. org/10.1002/2015rg000493

Cabanes C, Grouazel A, Kv Schuckmann, Hamon M, Turpin V, Coatanoan C, Paris F, Guinehut S, Boone C, Ferry N, Boyer Montégut Cd, Carval T, Reverdin G, Pouliquen S, Traon PYL (2013) The cora dataset: validation and diagnostics of in-situ ocean temperature and salinity measurements. Ocean Sci 9(1):1-18. https ://doi.org/10.5194/os-9-1-2013

Caldwell PM, Mametjanov A, Tang Q, Van Roekel LP, Golaz JC, Lin W, Bader DC, Keen ND, Feng Y, Jacob R, Maltrud ME, Roberts AF, Taylor MA, Veneziani M, Wang H, Wolfe JD, 
Balaguru K, Cameron-Smith P, Dong L, Klein SA, Leung LR, Li HY, Li Q, Liu X, Neale R, Pinheiro M, Qian Y, Ullrich PA, Xie S, Yang Y, Zhang Y, Zhang K, Zhou T (2019) The doe e3sm coupled model version 1: description and results at high resolution. J Adv Model Earth Syst 11:4095-4146. https://doi. org/10.1029/2019MS001870

Chassignet E, Marshall D (2008) Gulf stream separation in numerical ocean models. Geophys Monogr Ser 177:39-61

Cherchi A, Fogli PG, Lovato T, Peano D, Iovino D, Gualdi S, Masina S, Scoccimarro E, Materia S, Bellucci A, Navarra A (2019) Global mean climate and main patterns of variability in the $\mathrm{cmcc}-\mathrm{cm} 2$ coupled model. J Adv Model Earth Syst 11:185-209. https://doi. org/10.1029/2018MS001369

Collins M, Knutti R, Arblaster J, Dufresne JL, Fichefet T, Friedlingstein P, Gao X, Gutowski WJ, Johns T, Krinner G, Shongwe M, Tebaldi C, Weaver AJ, Wehner M (2013) Long-term climate change: projections, commitments and irreversibility. In: Stocker TF, Qin D, Plattner GK, Tignor M, Allen SK, Boschung J, Nauels A, Xia Y, Bex V, Midgley PM (eds) Climate change 2013: the physical science basis. Contribution of working group I to the fifth assessment report of the intergovernmental panel on climate change. Cambridge University Press, Cambridge. https://doi. org/10.1017/CBO9781107415324.025

Danabasoglu G, Yeager SG, Bailey D, Behrens E, Bentsen M, Bi D, Biastoch A, Böning C, Bozec A, Canuto VM, Cassou C, Chassignet E, Coward AC, Danilov S, Diansky N, Drange H, Farneti R, Fernandez E, Fogli PG, Forget G, Fujii Y, Griffies SM, Gusev A, Heimbach P, Howard A, Jung T, Kelley M, Large WG, Leboissetier A, Lu J, Madec G, Marsland SJ, Masina S, Navarra A, Nurser AG, Pirani A, Salasy Melia D, Samuels BL, Scheinert M, Sidorenko D, Treguier AM, Tsujino H, Uotila P, Valcke S, Voldoire A, Wang Q (2014) North atlantic simulations in coordinated ocean-ice reference experiments phase II (core-II). Part I: mean states. Ocean Model 73:76-107. https://doi.org/10.1016/j. ocemod.2013.10.005

de Boyer Montégut C, Madec G, Fischer AS, Lazar A, Iudicone D (2004) Mixed layer depth over the global ocean: an examination of profile data and a profile-based climatology. J Geophys Res 109(C12):003. https://doi.org/10.1029/2004JC002378

Delworth TL, Rosati A, Anderson W, Adcroft AJ, Balaji V, Benson R, Dixon K, Griffies SM, Lee HC, Pacanowski RC, Vecchi GA, Wittenberg AT, Zeng F, Zhang R (2012) Simulated climate and climate change in the GFDL CM2.5 high-resolution coupled climate model. J Clim 25(8):2755-2781. https://doi.org/10.1175/ JCLI-D-11-00316.1

Docquier D, Grist JP, Roberts MJ, Roberts CD, Semmler T, Ponsoni L, Massonnet F, Sidorenko D, Sein DV, Iovino D, Bellucci A, Fichefet T (2019) Impact of model resolution on arctic sea ice and north atlantic ocean heat transport. Clim Dyn 53(7):4989-5017. https://doi.org/10.1007/s00382-019-04840-y

Drijfhout S, van Oldenborgh GJ, Cimatoribus A (2012) Is a decline of AMOC causing the warming hole above the North Atlantic in observed and modeled warming patterns? J Clim 25(24):83738379. https://doi.org/10.1175/jcli-d-12-00490.1

Flato G, Marotzke J, Abiodun B, Braconnot P, Chou SC, Collins W, Cox P, Driouech F, Emori S, Eyring V, Forest C, Gleckler P, Guilyardi E, Jakob C, Kattsov V, Reason C, Rummukaine M (2013) Evaluation of climate models. In: Stocker T, Qin D, Plattner GK, Tignor M, Allen S, Boschung J, Nauels A, Xia Y, Bex V, Midgley P (eds) Climate change 2013: the physical science basis. Contribution of working group I to the fifth assessment report of the intergovernmental panel on climate change. Cambridge University Press, Cambridge

Fox-Kemper B, Adcroft A, Böning C, Chassignet E, Curchitser E, Danabasoglu G, Eden C, England M, Gerdes R, Greatbatch R, Griffies S, Hallberg R, Hanert E, Heimbach P, Hewitt H, Hill C,
Komuro Y, Legg S, Sommer J, Yeager S (2019) Challenges and prospects in ocean circulation models. Front Mar Sci 6:65. https ://doi.org/10.3389/fmars.2019.00065

Good SA, Martin MJ, Rayner NA (2013) EN4: quality controlled ocean temperature and salinity profiles and monthly objective analyses with uncertainty estimates. J Geophys Res 118:6704-6716

Gregory JM, Dixon KW, Stouffer RJ, Weaver AJ, Driesschaert E, Eby M, Fichefet T, Hasumi H, Hu A, Jungclaus JH, Kamenkovich IV, Levermann A, Montoya M, Murakami S, Nawrath S, Oka A, Sokolov AP, Thorpe RB (2005) A model intercomparison of changes in the Atlantic thermohaline circulation in response to increasing atmospheric $\mathrm{CO}_{2}$ concentration. Geophys Res Lett. https://doi.org/10.1029/2005GL023209

Grist JP, Marsh R, Josey SA (2009) On the relationship between the north atlantic meridional overturning circulation and the surfaceforced overturning streamfunction. J Clim 22(19):4989-5002. https://doi.org/10.1175/2009JCLI2574.1

Grist JP, Josey SA, Marsh R (2012) Surface estimates of the atlantic overturning in density space in an eddy-permitting ocean model. $\mathrm{J}$ Geophys Res 117(C06):012. https://doi.org/10.1029/2011JC007752

Haarsma R, Acosta M, Bakhshi R, Bretonniére PAB, Caron LP, Castrillo M, Corti S, Davini P, Exarchou E, Fabiano F, Fladrich U, Fuentes Franco R, García-Serrano J, von Hardenberg J, Koenigk T, Levine X, Meccia V, van Noije T, van den Oord G, Palmeiro FM, Rodrigo M, Ruprich-Robert Y, Le Sager P, Tourigny E, Wang S, van Weele M, Wyser K (2020) Highresmip versions of ECEarth: EC-Earth3p and EC-Earth3p-hr. Description, model performance, data handling and validation. Geosci Model Dev Discuss. https://doi.org/10.5194/gmd-2019-350 (In review )

Haarsma RJ, Roberts M, Vidale PL, Senior CA, Bellucci A, Bao Q, Chang P, Corti S, Fukar NS, Guemas V, von Hardenberg J, Hazeleger W, Kodama C, Koenigk T, Leung LR, Lu J, Luo JJ, Mao J, Mizielinski MS, Mizuta R, Nobre P, Satoh M, Scoccimarro E, Semmler T, Small J, von Storch JS (2016) High resolution model intercomparison project (highresmip). Geosci Model Dev 9:4185-4208

Heuze C (2017) North Atlantic deep water formation and AMOC in CMIP5 models. Ocean Sci 13(4):609-622. https://doi. org/10.5194/os-13-609-2017

Hewitt H, Bell M, Chassignet E, Czaja A, Ferreira D, Griffies S, Hyder P, Mcclean J, New A, Roberts M (2017) Will high-resolution global ocean models benefit coupled predictions on short-range to climate timescales? Ocean Model. https://doi.org/10.1016/j. ocemod.2017.11.002

Hirschi J, Barnier B, Böning C, Biastoch A, Blaker AT, Coward A, Danilov S, Drijfhout S, Getzlaff K, Griffies SM, Hasumi H, Hewitt H, Iovino D, Kawasaki T, Kiss AE, Koldunov N, Marzocchi A, Mecking JV, Moat B, Molines J, Myers PG, Penduff T, Roberts M, Treguier A, Sein D, Sidorenko D, Small J, Spence P, Thompson L, Weijer W, Xu X (2020) The Atlantic meridional overturning circulation in high resolution models. JGR Oceans. https://doi. org/10.1029/2019JC015522

Josey SA, Grist JP, Marsh R (2009) Estimates of meridional overturning circulation variability in the North Atlantic from surface density flux fields. J Geophys Res 114(C09):022. https://doi. org/10.1029/2008JC005230

Katsman CA, Drijfhout SS, Dijkstra HA, Spall MA (2018) Sinking of dense north atlantic waters in a global ocean model: location and controls. J Geophys Res Oceans 123:3563-3576. https://doi. org/10.1029/2017JC013329

Koenigk T, Fuentes R, Meccia V, Gutjahr O, Jackson L, New A, Ortega P, Roberts C, Roberts M, Arsouze T, Iovino D, Moine MP, Sein1 D (2020) Deep water formation in the North Atlantic Ocean in high resolution global coupled climate models. Ocean Sci (under review) 
Kuhlbrodt T, Jones CG, Sellar A, Storkey D, Blockley E, Stringer M, Hill R, Graham T, Ridley J, Blaker B, Calvert D, Copsey D, Ellis R, Hewitt H, Hyder P, Ineson S, Mulcahy J, Siahaan A, Walton J (2018) The low-resolution version of HadGEM3 GC3.1: development and evaluation for global climate. J Adv Model Earth Syst 10:2865-2888. https://doi.org/10.1029/2018MS001370

Lozier MS, Bacon S, Bower AS, Cunningham SA, Femke de Jong M, de Steur L, de Young B, Fischer J, Gary SF, Greenan BJ, Heimbach P, Holliday NP, Houpert L, Inall ME, Johns WE, Johnson HL, Karstensen J, Li F, Lin X, Mackay N, Marshall DP, Mercier H, Myers PG, Pickart RS, Pillar HR, Straneo F, Thierry V, Weller RA, Williams RG, Wilson C, Yang J, Zhao J, Zika JD (2017) Overturning in the Subpolar North Atlantic Program: a new international ocean observing system. Bull Am Meteorol Soc 98:737-752

Marsh R (2000) Recent variability of the North Atlantic thermohaline circulation inferred from surface heat and freshwater fluxes. J Clim 13(18):3239-3260. https://doi.org/10.1175/15200442(2000)013<3239:RVOTNA > 2.0.CO;2

McCarthy GD, Smeed DA, Johns WE, Frajka-Williams E, Moat BI, Rayner D, Baringer MO, Meinen CS, Collins J, Bryden HL (2015) Measuring the Atlantic meridional overturning circulation at 26N. Prog Oceanogr 130:91-111. https://doi.org/10.1016/j. pocean.2014.10.006

Mecking JV, Drijfhout SS, Jackson LC, Andrews MB (2017) The effect of model bias on Atlantic freshwater transport and implications for AMOC bi-stability. Tellus A Dyn Meteorol Oceanogr 69(1):1299910+. https://doi.org/10.1080/16000870.2017.12999 10

Menary MB, Hodson DLR, Robson JI, Sutton RT, Wood RA, Hunt JA (2015) Exploring the impact of cmip5 model biases on the simulation of North Atlantic decadal variability. Geophys Res Lett 42:5926-5934. https://doi.org/10.1002/2015GL064360

Menary MB, Kuhlbrodt T, Ridley J, Andrews MB, Dimdore-Miles OB, Deshayes J, Eade R, Gray L, Ineson S, Mignot J, Roberts CD, Robson J, Wood RA, Xavier P (2018) Preindustrial control simulations with HadGEM3-GC3.1 for CMIP6. J Adv Model Earth Syst 10:3049-3075. https://doi.org/10.1029/2018MS001495

Pardaens A, Gregory JM, Lowe JA (2011) A model study of factors influencing projected changes in regional sea level over the twenty-first century. Clim Dyn 36(9-10):2015-2033. https://doi. org/10.1007/s00382-009-0738-X

Roberts CD, Senan R, Molteni F, Boussetta S, Mayer M, Keeley S (2018) Climate model configurations of the ecmwf integrated forecasting system (ECMWF-IFS cycle43r1) for highresmip. Geosci Model Dev 11:3681-3712. https://doi.org/10.5194/ gmd-11-3681-2018

Roberts MJ, Hewitt HT, Hyder P, Ferreira D, Josey SA, Mizielinski M, Shelly A (2016) Impact of ocean resolution on coupled air-sea fluxes and large-scale climate. Geophys Res Lett 43:10430-10438

Roberts MJ, Baker A, Blockley EW, Calvert D, Coward A, Hewitt HT, Jackson LC, Kuhlbrodt T, Mathiot P, Roberts CD, Schiemann R, Seddon J, Vanniére B, Vidale PL (2019a) Description of the resolution hierarchy of the global coupled HadGEM3-GC3.1 model as used in cmip6 highresmip experiments. Geosci Model Dev Discuss. https://doi.org/10.5194/gmd-2019-148

Roberts MJ, Camp J, Seddon J, Vidale P, Hodges K, Vanniere B, Mecking J, Haarsma R, Bellucci A, Scoccimarro E, Caron LP, Chauvin F, Terray L, Valcke S, Moine MP, Putrasahan D, Roberts C, Senan $\mathrm{R}$, Zarzycki C, Ullrich P (2019b) Impact of model resolution on tropical cyclone simulation using the HighResMIP-PRIMAVERA multi-model ensemble. J Clim (under review)

Scaife AA, Copsey D, Gordon C, Harris C, Hinton T, Keeley S, O’Neill A, Roberts M, Williams K (2011) Improved atlantic winter blocking in a climate model. Geophys Res Lett 38(L23):703. https:// doi.org/10.1029/2011GL049573
Sein DV, Koldunov NV, Danilov S, Sidorenko D, Wekerle C, Cabos W (2018) The relative influence of atmospheric and oceanic model resolution on the circulation of the North Atlantic Ocean in a coupled climate model. J Adv Model Earth Syst 10:2026-2041. https://doi.org/10.1029/2018MS001327

Small RJ, Bacmeister J, Bailey D, Baker A, Bishop S, Bryan F, Caron J, Dennis J, Gent P, Hsu H, Jochum M, Lawrence D, Munoz E, diNezio P, Scheitlin T, Tomas R, Tribbia J, Tseng Y, Vertenstein M (2014) A new synoptic scale resolving global climate simulation using the community earth system model. J Adv Model Earth Syst 6:1065-1094. https://doi.org/10.1002/2014MS000363

Spall MA (2004) Boundary currents and watermass transformation in marginal seas. J Phys Oceanogr 34(5):1197-1213. https://doi. org/10.1175/1520-0485(2004)034<1197:BCAWTI>2.0.CO;2

Treguier A, Theetten S, Chassignet EP, Penduff T, Smith R, Talley L, Beismann JO, Böning C (2005) The North Atlantic subpolar gyre in four high-resolution models. J Phys Oceanogr 35:757-774. https://doi.org/10.1175/JPO2720.1

Voldoire A, Saint-Martin D, Senesi S, Decharme B, Alias A, Chevallier M, Colin J, Gueremy JF, Michou M, Moine MP, Nabat P, Roehrig R, SalasyMelia D, Seferian R, Valcke S, Beau I, Belamari S, Berthet S, Cassou C, Cattiaux J, Deshayes J, Douville H, Franchisteguy L, Ethe C, Geoffroy O, Levy C, Madec G, Meurdesoif Y, Msadek R, Ribes A, Sanchez-Gomez E, Terray L (2019) Evaluation of CMIP6 deck experiments with CNRM-CM6-1. J Adv Model Earth Syst 11:2177-2213. https://doi.org/10.1029/2019M S001683

Wang C, Zhang L, Lee SK, Wu L, Mechoso CR (2014) A global perspective on CMIP5 climate model biases. Nat Clim Change 4:201

Weaver AJ, Sedláček J, Eby M, Alexander K, Crespin E, Fichefet T, Philippon-Berthier G, Joos F, Kawamiya M, Matsumoto K et al (2012) Stability of the Atlantic meridional overturning circulation: a model intercomparison. Geophys Res Lett. https://doi. org/10.1029/2012GL053763

Williams KD, Copsey D, Blockley EW, Bodas-Salcedo A, Calvert D, Comer R, Davis P, Graham T, Hewitt HT, Hill R, Hyder P, Ineson S, Johns TC, Keen AB, Lee RW, Megann A, Milton SF, Rae JGL, Roberts MJ, Scaife AA, Schiemann R, Storkey D, Thorpe L, Watterson IG, Walters DN, West A, Wood RA, Woollings T, Xavier PK (2018) The Met office global coupled model 3.0 and 3.1 (GC3.0 and GC3.1) configurations. J Adv Model Earth Syst 10(2):357-380. https://doi.org/10.1002/2017ms001115

Winton M, Anderson WG, Delworth TL, Griffies SM, Hurlin WJ, Rosati A (2014) Has coarse ocean resolution biased simulations of transient climate sensitivity? Geophys Res Lett 41(23):85228529. https://doi.org/10.1002/2014GL061523

Wood RA, Keen AB, Mitchell JFB, Gregory JM (1999) Changing spatial structure of the thermohaline circulation in response to atmospheric $\mathrm{CO}_{2}$ forcing in a climate model. Nature 399(6736):572575. https://doi.org/10.1038/21170

Woollings T, Gregory JM, Pinto JG, Reyers M, Brayshaw DJ (2012) Response of the North Atlantic storm track to climate change shaped by ocean-atmosphere coupling. Nat Geosci 5(5):313-317. https://doi.org/10.1038/ngeo1438

Yokohata T, Emori S, Nozawa T, Ogura T, Okada N, Suzuki T, Tsushima Y, Kawamiya M, Abe-Ouch A, Hasumi A, Sumi A, Kimoto M (2007) Different transient climate responses of two versions of an atmosphere-ocean coupled general circulation model. Geophys Res Lett 34(L02):707. https://doi.org/10.1029/2006GL027966

Zou S, Lozier M, Li F, Abernathy R, Jackson L (2020) Density-compensated overturning in the Labrador Sea. Nat Geosci 13:121126. https://doi.org/10.1038/s41561-019-0517-1

Publisher's Note Springer Nature remains neutral with regard to jurisdictional claims in published maps and institutional affiliations. 